\title{
A descriptive and quantitative approach regarding erosion and development of landforms on abandoned mine tailings: new insights and environmental implications from SE Spain
}

\section{Short title: landforms on abandoned mine tailing deposits}

\author{
J.F. Martín Duque ${ }^{\mathrm{a}}$, I. Zapico ${ }^{\text {a }}$, R. Oyarzun ${ }^{\mathrm{b}}$, J.A. López García ${ }^{\mathrm{b}}$, P. Cubas ${ }^{\mathrm{c}}$ \\ ${ }^{a}$ Departamento de Geodinámica, Facultad de Ciencias Geológicas, Universidad Complutense e Instituto de \\ Geociencias, IGEO (CSIC, UCM), 28040 Madrid, Spain \\ ${ }^{b}$ Departamento de Cristalografía y Mineralogía, Facultad de Ciencias Geológicas, Universidad Complutense, \\ 28040 Madrid, Spain \\ ${ }^{c}$ Departamento de Biología Vegetal II, Facultad de Farmacia, Universidad Complutense, 28040 Madrid, Spain \\ *Corresponding author.Tel.:+34 913944857; josefco@ucm.es.
}

\begin{abstract}
The San Cristóbal-Perules mining site in Mazarrón in southeast Spain was subjected to about a hundred years of intense mining activity for lead, silver, and zinc. Metallurgical operations (smelting, calcination, gravity concentration) carried out during the late nineteenth century early twentieth century induced significant land transformation, and the most conspicuous wastes of this period consists of a chaotic piling of 'old' tailing deposits. Later on, during the mid- twentieth century, 'modern' tailings resulting from froth flotation were accumulated filling small valleys; these latter valley-fill tailings rose sequentially according to the upstream construction method, progressively raising the level of the dam during the process. Once abandoned, both types of tailing deposits underwent severe erosion, resulting in a
\end{abstract}


mosaic of erosional and sedimentary landforms developed upon (e.g., gully formation) and within them (e.g., piping). We made an inventory and classification of these landforms. Our study shows the geomorphic work to reestablish a new steady state between the tailings deposits and the local erosive conditions. This scenario implies several hazards related to the extremely high heavy metal contents of these tailings and the geomorphic instability of the deposits. We also quantified the tailings tonnage and erosion that occurred at one of the tailings dams (El Roble). As shown by an oblique aerial photograph taken in 1968, this dam had a terraced topography, whereas in 2013 this morphology had evolved into a badland-type relief with deep parallel gullies. By recognizing and surveying specific, remnant points along the benches and outslopes of the older terraced topography, we were able to build up a first digital elevation model $\left(\mathrm{DEM}_{1}\right)$ reflecting the initial topography. A second DEM, this time showing the present topography, allowed quantification of erosion via Material Loss $=\mathrm{DEM}_{1}$ - $\mathrm{DEM}_{2}$. This yields an erosion rate (1968-2009) of $151.8 \mathrm{Mg}$ (MT) ha ${ }^{-1} \mathrm{y}^{-1}$, which matches well typical values for erosion of mined areas, commonly above $100 \mathrm{Mg}(\mathrm{MT}) \mathrm{ha}^{-1} \mathrm{y}^{-1}$. Abandoned mine tailing deposits are extremely common in the semiarid scenarios of the SW USA, Australia, Chile, and Peru. Given the similarities of these scenarios with SE Spain, the example from Mazarrón may provide useful new insights regarding the erosion and geomorphic evolution of such tailing deposits. These matters should be addressed in key environmental actions such as mine closure plans and land reclamation projects. A solution may come via restoration of these deposits through landform design involving the building up of stable mature landscapes, which in turn can withstand erosion much more easily.

Keywords: Mazarrón; SE Spain; mining; erosion of tailing deposits; descriptive and environmental geomorphology; landform design 


\section{Introduction}

\subsection{Background}

Geomorphology is the interdisciplinary and systematic study of landforms and their landscapes as well as the earth surface processes that create and change them (IAG, 2014). Despite that all landforms of the Earth's surface are potentially included under that definition, the truth is that geomorphology has traditionally focused on landscapes that have not undergone significant anthropic modification by earth movement. However, the percentage of the Earth's land surface subjected to human modification by earth moving activities has grown significantly in the last decades, and the likely forecast is that it will not stop growing in the forthcoming future (e.g., Rivas et al., 2006; Hooke et al., 2012), as shown by fastdeveloping countries such as China, India, or Brazil (among others). Humankind has moved and is moving huge amounts of earth thus creating new landforms, a process that often leads to accelerated erosion. The sediments derived from the latter process end up as colluvium on the hillslopes and as alluvium in the floodplains, thus subtly altering the shape of the land. The rest is carried away by streams and rivers. Taking all these matters into consideration, two facts must be highlighted: (i) landscapes modified by earth movement activity are becoming a key issue in geomorphology; and (ii) the environmental effects of these new landscapes (runoff from these areas is commonly contaminated and has a high sediment load) and the associated risk potential involving mass movements (flooding, loss of human life, economic catastrophes, etc.) are of paramount importance. This confers to geomorphology (together with environmental geochemistry in the case of abandoned mine sites) a leading role 
in the understanding of the roots of the problems and in the search for sound closure plans, reclamations and management solutions.

This paper is focused on 'minescapes'-here defined as landscapes generated by mining activity - and in this regard, despite the evident morphological modification that they undergo, most of the research and literature on the subject has focused on geomorphologically based assessments of mining-affected catchments. Langedal (1997) and James (2005) studied the geomorphic implications of dams built to stop fluvial dispersion of tailings. Taylor and Kesterton (2002) researched the dispersal of high metalliferous pollution from spoil heaps derived from copper mining in the Gruben River valley of Namibia. Macklin et al. (2006) showed how the understanding of sediment-associated metal dispersion processes in rivers can be used in a practical way to help river basin managers more effectively control and remediate catchments affected by present and historical metal mining. Lecce and Pavlowsky (2014) assessed the magnitude and distribution of mercury $(\mathrm{Hg})$ and copper $(\mathrm{Cu})$ contamination of floodplain deposits associated with nineteenth century gold ( $\mathrm{Au}$ ) mining activities in the Gold Hill mining district of North Carolina.

Other studies linking geomorphology and mined lands have focused on: (i) criteria for their geomorphic reclamation (Bugosh, 2007); (ii) the application of geomorphic evolution models, under and outside of reclamation measurements (Riley, 1995; Evans and Loch, 1996; Willgoose and Riley, 1998; Evans et al., 2000; Hancock et al., 2003); and (iii) the monitoring of geomorphically reclaimed lands (Martín-Duque et al., 2010). However, very few studies (e.g., Haigh, 1979, 1980) have dealt with actual 'mining geomorphology'. Two examples from Belgium are provided by Nyssen and Vermeerch (2010) and Beullens et al. (2014). The former analyzes the spatial distribution of the main geomorphic processes occurring on coal tips, whereas the second one shows the high impact of slope morphology on the magnitude of rill erosion on coal mine spoil heaps. 


\subsection{Tailing dams and derived hazards: a brief introduction}

The volumes of tailing deposits (creating large new landforms) can be huge; for example, a large mine such as Escondida in Chile is expected to dispose 3.3 billion metric tons of tailings during the period 2003-2043 at its local impoundment facility of Laguna Seca (Chambers et al., 2003). Even relatively small-scale operations may alter the landscape so profoundly as to eliminate an entire bay with its harbor facilities as it happened in Portman (Spain) (Oyarzun et al., 2013), not far from our study area. The Peñarroya Mining and Metallurgical Company disposed at Portman Bay about 60 million tons of tailing materials directly to the Mediterranean Sea between 1957 and 1990; a substantial part of it (12.5 Mt) was dragged back by the sea currents progressively infilling the bay, making the shoreline advance between 500 and $600 \mathrm{~m}$ seaward (Manteca et al., 2014) thus creating a massive, physical and chemical environmental impact (Oyarzun et al., 2013).

Tailing dams are one of the most unstable minescapes, resulting in evident hazards. These hazards are chemical (leaching and transport of heavy metals and metalloids) and physical (failure of the dam) or a combination of both. Tailing dams may fail because of many reasons, among them, they are not built to last. In fact, different from civil engineering works such as road or tunnel construction, in mining operations the works are basically designed to endure the mine life cycle and little more. A typical case of dam failure relates to piping that occurs if seepage within or beneath the embankment causes erosion along its flowpath. In this respect, excessive piping may result in local or general failure of the embankment (WISE, 2014). The consequences can be catastrophic if human settlements are located in the vicinity of a tailings dam and may affect large areas if the residues reach a river. A situation of this type can develop even if no dam failure happens; all is required is the 
strong erosion of the tailings dam and a nearby river, as it happens to be in the case of Mazarrón where massive earth removal has taken place in the last 45 years or so. In this regard, the older a tailings dam is the greater and cumulative become the risks, a fact well exemplified by the high heavy metal contents along the Las Moreras seasonal river, which runs alongside the San Cristóbal-Perules mined site in the Mazarrón district (Oyarzun et al., 2011) (see Figs. 1 and 2). Two previous works on the Mazarrón district (Acosta et al., 2011; Oyarzun et al., 2011) indicate the potential contamination risk associated with the tailing deposits. However, a geomorphological approach (either qualitative or quantitative) is not provided by either of them, and this is the focus of this paper.

\subsection{Aims and research questions}

Based on detailed field work and topographical quantification carried out at the referred Mazarrón district (Murcia, Spain) (Fig. 1) —one of the classic and oldest $\mathrm{Pb}-\mathrm{Zn}$ mining sites in Europe- we sought to: (i) make an inventory, classification, description, and interpretation (relating geomorphology and geochemistry) of the landforms existing in the tailings dams; (ii) quantify the tailings tonnage and erosion that occurred at the El Roble dam; (iii) interpret the erosive characteristics of the tailings and its hydrological connectivity as a key factor for environmental effects and risk potential. By providing new insights into these matters, we pursued answering these questions: (i) what are the main geomorphic processes currently acting upon these tailing deposits and mobilizing sediments, and how do they operate?; (ii) what is the magnitude of the erosive process at the tailing dams of this minescape?; and (iii) what is the meaning of the highly erosive character of this minescape and what is its hydrological connectivity framework? From this information, we finally sought to assess alternative, geomorphic-based reclamation strategies, asking ourselves if a geomorphic 
reclamation approach is applicable for tailing deposits. All that focusing on an environmental geomorphology perspective, a discipline originally defined as the practical use of geomorphology for the solutions of problems where man wishes to transform or to use and change superficial processes (e.g., Panizza, 1996).

\section{Regional setting}

\subsection{Physiography and climate}

The physiographic setting of Mazarrón is laid by three sierras (Algarrobo, Las Moreras, and Almenara), with altitudes ranging from 400 to 700 m; and the San Cristóbal-Perules mined site is located at the footslope of the Sierra del Algarrobo, surrounded by small volcanic hills (Fig. 1). These sierras define a horseshoe-shaped sedimentary basin (Mazarrón), opened to the north and slightly inclined to the south. The basin is drained by the Rambla de Las Moreras, which receives sediments from the sierras, the basin itself, and in its lower course, from the San Cristóbal-Perules mine site. The mining wastes are located at about $5.5 \mathrm{~km}$ from the coast (Fig. 1). The major man-made landforms at this location are the result of metallurgical activities and consist of tailing deposits and rock waste dumps (Fig. 3). However, apart from dirt roads and cuts there are no truly large excavations (e.g., open pits) because mining was mostly underground. Rambla is a Spanish term referring to wadi: ephemeral fluvial channels of semiarid and arid areas. These wadis have a flat stream bed with vertical banks. They are dry most of the year and are only functional under torrential rainfall, giving rise to flash floods, and able to move high quantities of bedload, suspended sediment, and dissolved cations and anions. 
The area is characterized by a semiarid Mediterranean climate (Fig. 1), with raindeprived summers and moderation of temperatures by the influence of the Mediterranean Sea. Annual rainfall may strongly vary between years, but it is within the range of $185-310 \mathrm{~mm}$; whereas average annual temperatures are between 16.5 and $18.8^{\circ} \mathrm{C}$ (García-Rizo et al., 1999). Although rainfall is not high, the area is subjected to annual, strong stormy episodes that can induce important flash flood phenomena. The semiarid climate of SE Spain may have started as early as $\sim 4500 \mathrm{BP}$ (before present), with a radical transformation of the landscape that reflects in the establishment of the steppe conditions found today (Pantaleón-Cano et al., 2003). Because of the scarcity of precipitation that characterizes the climate of the region, most of the soils lack a B horizon, and therefore C profiles are dominant. Calcic xerosols, haplic calcisols, and calcaric regosols, typical of semiarid Mediterranean 'caliches', along with lithosols, are common in the slopelands; whereas calcaric fluvisols typify the floodplains of the Las Moreras wadi (IDERM, 2009-2014). The areas affected by mining and metallurgical activities can be classified as anthrosols and technosols (Oyarzun et al., 2011).

\subsection{Geological setting, ore deposits, mining history, and wastes}

\subsubsection{Geology and mineral deposits}

Mazarrón is located within the $160 \mathrm{~km}$-long-Almería-Cartagena volcanic belt (Oyarzun et al., 1995). This Miocene belt comprises a variety of volcanic series including calc-alkaline, high-K calc-alkaline, and shoshonitic rocks. The area of Mazarrón is also characterized by the presence of two of the most important Alpine metamorphic complexes of southern Spain: Alpujarride and Nevado Filábrides (mainly carbonates and schists) (Fig. 1). In Mazarrón, the volcanic activity gave rise to andesites, dacites, and rhyodacites of Tortonian to Messinian age that were emplaced as subvolcanic domes and ashfall deposits (tuffs) (Fig. 1). The 
volcanic rocks form an inner ring within the horseshoe structure bounding the Mazarrón basin, infilled during Tortonian-Messinian and Pliocene by marine sediments comprising marls, sandstones, conglomerates, and coquina limestones. The southern realm of the volcanic rim hosts $\mathrm{Pb}-\mathrm{Zn}-\mathrm{Ag}-\mathrm{Cu}$ deposits of the vein and stockwork type; whereas the main ore deposits clusters are (from west to east): Coto Fortuna, Pedreras Viejas, and San Cristóbal-Perules (Fig. 1). These clusters are characterized by the presence of dacitic to rhyodacitic domes that underwent strong and pervasive advanced argillic alteration, with kaolinite, alunite and silica formation. Main ore minerals are pyrite, sphalerite, and Agbearing galena; whereas other sulphides include chalcopyrite, tetrahedrite-tennantite, arsenopyrite, cinnabar, stibnite, and berthierite (e.g., Oyarzun et al., 2011).

\subsubsection{Mining history and resulting waste deposits}

The district was first mined for lead in Roman time, later for the alum (aluminium sulphate: alunite) during the fifteenth to sixteenth centuries; then for the alum wastes from 1774 to 1953; and finally for lead, silver, and zinc during the nineteenth to twentieth centuries (until the early 1960s). Galena ( $\mathrm{PbS}$ ) was separated from the $\mathrm{Pb}-\mathrm{Zn}$ ore using gravity concentration with jigs; in turn, this concentrate was sent to reverberatory smelting of galena-rich ore to obtain lead metal, a process that must have started in 1886 when two large furnaces were installed at San Cristóbal-Perules. It was not until 1951 that zinc was selectively extracted from the Mazarrón ores. In this regard, the tailing deposits of the San Cristóbal-Perules area unequivocally correspond to the 1960 s decade, as it is reflected in a valuable set of oblique aerial photographs dated in 1968 (Fig. 4). By the early 1970s all mining activities had ceased; however, the wastes from these operations remained in the area (Fig. 5).

The main mine waste deposits at Mazarrón were derived from either gravity concentration or froth flotation procedures (modern tailings; e.g., El Roble dam). Froth 
flotation (e.g., Kawatra, 2011) physically separates particles based on differences in the ability of air bubbles to selectively adhere to specific mineral surfaces (ore minerals) in a mineral-water slurry; the particles with attached air bubbles are then carried to the surface and removed, whereas the particles that remain completely wetted (gangue minerals) stay in the liquid phase and form the 'tailings'. The usual procedure continues by sending the 'concentrate' (rich in base metal sulfides) to a smelter, whereas the tailings are disposed at a specially designed impoundment facility, which is usually near to the flotation plant. In this regard, more than $95 \%$ of the milled mined material (or 'head') that enters the flotation plant will go into the tailings impoundment as a slurry (or 'pulp') where it eventually dries out after the operation ends (e.g., Oyarzun et al., 2013). However, this is partially true only because, unless a waterproof sealing is laid upon the tailings (which is rarely the case in abandoned mines), the rain water will continuously manage to get into the deposit. Given that the tailings are usually rich in pyrite, the vadose zone will be subjected to constant oxidation of sulphides and therefore the leaching of heavy metals and metalloids, thus converting the tailings in live chemical reactors. This is well exemplified at San Cristóbal-Perules by the seasonal formation of red ponds of acid mine drainage on top of the tailings.

The San Cristóbal-Perules mining site hosts two types of tailing deposits: (i) those made of a chaotic piling of tailings (or old tailing deposits) that correspond to the late nineteenth century - early twentieth century industrial activities, and (ii) proper (or modern) tailing deposits (valley-fill type) raised sequentially using the 'upstream' construction method during the mid- twentieth century, following the level of the impounded tailings during the filling process (Fig. 4). The latter procedure, while available at low cost, implies a number of specific hazards related to dam stability. These mine tailings are extremely rich in $\mathrm{Pb}$ (mean = $\left.12,400 \mu \mathrm{g} \mathrm{g}^{-1}\right)$ and $\mathrm{Zn}\left(\right.$ mean $\left.=6100 \mu \mathrm{g} \mathrm{g}^{-1}\right)$, whereas As concentrations are very high $($ mean $=$ $650 \mu \mathrm{g} \mathrm{g}^{-1}$ ) (Oyarzun et al., 2011). From a mineralogical point of view, the tailings are rich in 
quartz, feldspar, kaolinite, and illite, but also contain pyrite $\left(\mathrm{FeS}_{2}\right.$; main sulphide phase), galena $(\mathrm{PbS})$, and sphalerite $(\mathrm{ZnS}$; the main source of arsenic). The continuous oxidation of pyrite results in formation of complex hydrated sulphates of variable composition (e.g., gypsum: $\mathrm{CaSO}_{4} \cdot 2 \mathrm{H}_{2} \mathrm{O}$; rozenite: $\mathrm{FeSO}_{4} \cdot 4 \mathrm{H}_{2} \mathrm{O}$ ), basic sulphates such as alunite $\left(\mathrm{KAl}_{3}\left(\mathrm{SO}_{4}\right)_{2}(\mathrm{OH})_{6}\right)$, jarosite $\left(\mathrm{KFe}_{3}\left(\mathrm{SO}_{4}\right)_{2}(\mathrm{OH})_{6}\right.$, and goethite $(\mathrm{FeO}(\mathrm{OH}))$. The hydrated sulphates are unstable chemical byproducts in the tailings, being constantly subjected to precipitation-dissolution cycles during dry and wet conditions, respectively. This plays a major role in the physical stability (and geomorphic activity) of the tailing materials because erosion will be enhanced by the loss of the mineralogical cement that keeps the grains together. Besides, instability of the tailings is further increased by the scarcity of vegetation in the San Cristóbal-Perules minescape, which cannot provide an effective and protective vegetation cover against water erosion (Moreno-de las Heras et al., 2009). The plants and shrubs disappear altogether on top of the tailing deposits (Fig. 5), which is easy to understand given the extremely high metal contents of the tailings. Nevertheless some resilient plants grow on the slopes and have colonized mine rock wastes, the most conspicuous plant being Salsola oppositifolia, a bush that withstands high salinity levels. On the surrounding slopes neighboring the mined lands, patches of the natural vegetation still persist, including bushes and shrubs of Ziziphus lotus (Iberian jujube), Withania frutescens (oroval, a member of the nightshade family), Salsola oppositifolia (salao borde, a saltwort), Launaea arborescens (cardaviejo, a spiny species of the daisy family), Asparagus albus (a wild asparagus), Capparis spinosa (caper bush), Thymus sp. (thyme), and Dianthus broteroi (a wild carnation); perennial tussock grasslands of Stipa tenacissima (esparto grass); and naturalized plants such as Zygophyllum fabago (Syrian bean-caper). These are the plants (and their closer relatives or ecologically equivalent in other world regions) that should be used in land reclamation works on minescapes with similar climatic and orographic conditions to those of Mazarrón. 


\section{Material and methods}

A detailed field work survey was done in September 2013 for the reconnaissance of landforms denoting geomorphic activity at the abandoned tailing deposits of El Roble and its surroundings. We searched for unequivocal signs of current superficial dynamics (e.g., 'fresh' scarps) along with identifying landform types and patterns universally accepted in the geomorphic literature. The landforms were process-based classified, described, and genetically interpreted. The waste deposits affected by these processes correspond to the old and modern tailing deposits (see above Section Mining history).

To calculate the tonnage of tailings from the El Roble dam in the San CristóbalPerules area, we first built a triangular irregular network (TIN) representing the detailed topography of the valley fill, at its present state, and a portion of its surroundings. To build this TIN, we used the available high resolution LIDAR data, with a minimum point density of 0.5 points $\mathrm{m}^{-2}$ (PNOA, 2009), and ArcGIS 10.2.2 software (ESRI, 2013). From this TIN, 1-m contours were generated for the referred area. Then, the contours within the tailings dam polygon were deleted. Subsequently, the contours of the original unfilled valley for the same area were interpreted. The criteria for interpretation were to correlate the radius of curvature and the contour spacing according to the topographical maps and an aerial photograph from 1956 (before the valley fill began). After that, we built a TIN representing the estimated unfilled valley topography. Finally, the two TINs, the one without the tailings dam (reconstructed) and the one with the actual tailings dam (PNOA, 2009), were compared geometrically, using the surface difference tool of the ArcGIS 10.2.2 software. The difference in volume between the two TINs was obtained, representing the total volume of tailings 
filling El Roble valley head. To estimate the tonnage (metric tons: MT), we multiplied the volume by the bulk density of the tailings. The latter was obtained by hydrostatic weighing at the Engineering Geology Laboratory of the Complutense University of Madrid, using samples gathered during the field work campaign of September 2013.

To quantify the total erosion at the El Roble dam, we first inspected the remnants of its 19 consecutive former terraces (Fig. 7). The benches and outslopes of this dam (as those of most tailing dams) have no uniform width and height, and therefore, their boundaries are three-dimensional breaklines. This is because tailing dams are not initially constructed to completion, but raised sequentially as the impoundment gets filled (WISE, 2014). Because mineral extraction rates from a mine fluctuate along the mine life cycle (because of geologic, engineering, or economic conditions), the terraces are bound to be different in height and even in composition (some may be more reactive than others). We used a GPS Leica 1200 instrument to identify and locate the remaining well-defined breaklines (although erosion has blurred some of them) at specific points (Fig. 8). These points were labelled based on whether they were the head (outer boundary of bench) or the toe (inner boundary of bench) of the outslope, taking also into consideration their XYZ position at the terraces. From this surveyed XYZ point cloud and their spatial reference and with the help of the oblique aerial photo (Fig. 7), we digitized two-dimensional breaklines linking points that originally formed part of the same three-dimensional breakline. The next step was to give heights to the points that defined the digitized two-dimensional breaklines, establishing a new point cloud with the heights that must have had the three-dimensional breaklines in 1968. For those terraces without remnant breaklines, the heights were defined taking into account those of the closest remaining breaklines and a standard size defined for the regular pattern of the terraces. From this new point cloud, we converted the two-dimensional breaklines into three-dimensional breaklines. We used ArcGIS 10.2.2 (ESRI, 2013) to generate a Triangular Irregular Network 
(TIN) for a virtual reconstruction of the terraced topography of the tailings dam in 1968. The TIN representing the detailed topography of the eroded tailings dam was built upon the available high resolution LIDAR point cloud, with a minimum point density of 0.5 points $\mathrm{m}^{-2}$ (PNOA, 2009). Subsequently, the two TINs, the one of the reconstructed topography of the tailings dam as of 1968 and the one of the eroded tailings dam (obtained from the LIDAR data of 2009), were geometrically compared (subtracted), allowed quantification of erosion via Material Loss $=\mathrm{DEM}_{1}-\mathrm{DEM}_{2}$, by using the surface difference tool of the ArcGIS 10.2.2 software. Their direct comparison was possible because both TINs had the same coordinate system. The difference in volume between the two TINs represents the total volume of eroded material in 41 years. To get the total eroded material in tons, we multiplied it by its bulk density.

\section{Results and discussion}

\subsection{Main geomorphic features within the San Cristóbal-Perules minescape}

Figure 9 compiles a selection of representative examples of the inventoried landforms, and Fig. 10 shows their location. A description and analysis of the forms follow.

\subsubsection{Weathering landforms}

Physical and chemical weathering at the San Cristóbal-Perules minescape is disaggregating the tailings, thus favoring their detachment and transport by geomorphic agents and processes. The most obvious one is a superficial popcorn crust layer (1 in Fig. 9), which covers specific areas of the tailing deposits. This layer shows randomly oriented chips, highly irregularly shaped aggregates resembling desiccation racks, with sizes ranging between 5 and $10 \mathrm{~cm}$ 
width and $<2 \mathrm{~cm}$ depth. These cracks are interpreted as a result of repeated processes of wetting (swelling) and drying (shrinking), related to chemical reactions of the sulphates. The hydrated sulphates are unstable chemical byproducts in the tailings, being constantly subjected to precipitation-dissolution cycles during dry and wet conditions, respectively. When they are located on slopes, small slab failure processes occur, mobilizing materials downslope. Once saturation occurs, small mudflows and microslumps affect this crust.

\subsubsection{Water erosion landforms}

Erosion, transport, and sedimentation by running water are the most efficient geomorphic processes at the San Cristóbal-Perules minescape. Runoff and truly fluvial processes detach, move downslope, and locally deposit high amounts of mine deposits, forming erosion pillars or pedestals, sandpaper-like surfaces, rills, gullies, badland-like terrains, braided sand-bed channels and alluvial cones. Erosion pillars or pedestals (2 in Fig. 9) are small $(10-5 \mathrm{~cm}$ in height) earth microtowers (or miniature 'hodoos' or 'dames coiffees') capped by remnants of ferricretes that appear at flat surfaces and low-gradient slopes of the tailing deposits. Ferricretes and hardpans are a common feature in tailing deposits from SE Spain (e.g., Oyarzun et al., 2013; Manteca et al., 2014), capping the deposits with a hard, brownishcoloured, erosion-resistant cover. These erosional forms are the result of raindrop impact on weakly consolidated mine deposits. The remnants of ferricretes protect the underlying sediment from raindrop impact, resulting in the formation of the pillars.

Sandpaper-like surfaces (3 in Fig. 9) develop at silt and sandy low-gradient slopes, mostly located just downslope of rounded divides along the tailing deposits. This denotes sheet erosion - a continuous sheet of water that covers the surface completely, mobilizing the smallest particles downslope. The location of these surfaces at the convex part of rounded 
divides (at gently sloping surfaces), just below them, is conditioned by the fact that, at these positions, the runoff has not accumulated enough to form rills.

We differentiated two types of rills, as they are different according to the slope in which they developed. We did this following Brice's (1966) classification for gullies, broadly divulgated by Campbell (1997). Although this classification was not proposed for rills, the same principles apply. Rills on upland surfaces (such as former beach areas of the sedimentation area behind the tailings dam) are small channels or grooves of the order of a few centimeters in width and in depth, with a dendritic drainage pattern (4a in Fig. 9). They are the result of concentration of runoff at the surface, caused by irregularities in the surface and by an excess in the runoff. Hence sheet water begets rills by its accumulation into channels, eroding their bottom and sides. Rills on slopes (4b in Fig. 9) are small channels or grooves of the order of a few centimeters in width and depth that, different from the dendritic drainage pattern of the upland surfaces, form parallel lines following the direction of the maximum gradient. Their origin is as just explained for rills on upland surfaces, their main difference being that the slope (gradient) is higher here; this means that runoff erosivity is higher, and therefore, the transition from sheet erosion to rill erosion occurs at lower distances from the divides.

According to the slope in which they develop, Brice's (1966; in Campbell, 1997) classification for gullies (as a function of the physiographic position in which they appear) is totally applicable here. Gullies on upland surfaces (such as former beach areas of the sedimentation area behind the tailings dam) are linear incisions (with steep slopes and headwalls) characterized by intense erosion and sufficient extent (in the order of magnitude from decimeters to meters) as to be permanent landforms of the landscape (Brice, 1966; Torri and Borselli, 2003) (5a in Fig. 9). On these upland surfaces, they usually expand on undissected surfaces by headcutting, which makes the knickpoints (identifiable in the field) 
migrating upstream. Because of the low gradient of these upland surfaces, their drainage pattern is dendritic. The same definition of gullies according to Brice (1966) and Torri and Borselli (2003) applies to gullies on slopes (5b in Fig. 9). In these cases, due to the high gradient of these steep slopes, their drainage pattern is parallel. While the term 'badlands' is associated with parts of deserts, we have classified some areas of these abandoned tailing deposits as badlands-like landforms (5c in Fig. 9) because they are similar in definition: barren and usually intricately dissected terrain, cut by rills and gullies, with complex microrelief (popcorn, cracks, pipes, knife-edge and rounded divides...) (see Campbell, 1997). The main difference between the landforms existing here and the typical badlands that are natural (or human-induced) components of arid zone landscapes is their size, much larger in the latter.

A network of dry washes develops on the flat surfaces of the tailing deposits, showing braided, sand-bed channels (6 in Fig. 9). Their beds are comprised of bedforms with a welldefined braided pattern with complex bars on which chutes are developed. At the surface of the wash complex, hydrated sulfates of variable composition appear (e.g., gypsum: $\mathrm{CaSO}_{4} \cdot 2 \mathrm{H}_{2} \mathrm{O}$; rozenite: $\mathrm{FeSO}_{4} \bullet 4 \mathrm{H}_{2} \mathrm{O}$; etc.). We deduce that these bedforms are a result of the interactions between coarse and fine fractions during bedload transport of the intrinsically heterogeneous-sizing tailing deposits. We also interpret the freshness of the landforms as a frequent activity of small (low-depth) flash flood events. Small coalescent alluvial cones (7 in Fig. 9) form where gullies on slopes and badlands-like slopes on tailings emerge to flat surfaces. Sedimentation occurs as a consequence of change of slope, where the loss of channel confinement and flow velocity propitiates the sedimentation with cone morphology, with the apex located at the mouth of the gully. Most of the identified cones are located on the top of tailing platforms at lower elevations than the eroded slopes, consequently without hydrological connection with the environment outside the mine but with risk of connection 
with the fluvial network - for instance, gullies on upland surfaces can reach these cones by upstream migration, or headcutting.

\subsubsection{Mass movement landforms}

Completing the catalogue of the main geomorphic features within the San Cristóbal-Perules minescape are a series of landforms created by gravitational processes. The most accepted classifications for them include the material that is mobilized and the type of movement. For the tailing deposits of Mazarrón, the affected terrain is composed by residual earth material, and therefore, we find three types of earth movements: earth slides, earth topples, and earth falls. Finally, collapse headwalls and collapse sinks, common also at this minescape, must also be included as types of gravitational processes.

A series of scars of earth slides (8 in Fig. 9) occur at the platform-slope edges of the tailing deposits. Despite the dominant dry conditions of the area, we interpret that these movements occur in wet conditions after either intense or continuous rainfall events. During these events, the flat-top surfaces of the tailing deposits infiltrate water, which increases the water pore pressure buildup of the mine deposits. An increasing of the pore pressure decreases the material's cohesion, triggering slope instability. Earth topples (9a in Fig. 9) appear at the steep (almost vertical) slopes of gullies on upland surfaces. The movement is rotational toward the exterior of the gullies' banks. These movements are triggered by flow undercutting at the base of the gullies' walls, mostly at external banks of meanders, where the flow concentrates. These gravitational processes move material from the gullies' walls to their bottoms, where they are temporally stored, waiting to be transported downstream in subsequent flow events. Earth falls (9b in Fig. 9) are different from the topples because in this case the material falls from the gullies' banks to their base without any rotational movement, forming a continuous small debris (talus) slope. This process is triggered by flow undercutting 
at the base of the gullies' walls at straight stretches of the gullies or by a loss of cohesion of the gullies' banks. These gravitational processes are coupled with fluvial ones so that once this material moves from the gullies' walls to the gullies' bottoms, it will be transported downstream in subsequent flow events.

Waste and tailing deposits of the El Roble surroundings are also affected by collapses. When the collapses occur in linear caves, they form collapse headwalls (10a in Fig. 9), initiating gully formation. We interpret these collapses as a consequence of piping processes (also called tunnel erosion or pseudokarst) - a subsurface erosion process in which percoline-controlled flowing water removes soil particles. Therefore, a subterranean drainage network forms. Once these cavities collapse, their surfaces form gullies' headwalls. We interpret the occurrence of piping here as a consequence of any of the following factors: (i) the soil particles of the tailings are cemented by sulphates - unstable chemical byproducts in the tailings - so that dissolution processes at wet conditions of these hydrated sulphates dissolve the cement and soil particles become loose; or (ii) the presence of alternating layers of permeable and impermeable materials at the tailing deposits, which may have facilitated lateral flow of water within them, coupled with the presence of outlets of the pipe systems at the tailing slopes, favoring the formation of the pipes. We interpret that piping has a key role in this minescape of the Mazarrón abandoned mine deposits. When the collapses happen in a specific point, they have a truly funnel morphology (collapse sinks, 10b in Fig. 9), very similar to that of limestone sinkholes. Collapse sinks are also interpreted as a consequence of piping. Spontaneous combustion of carbon spoil heaps has been reported to give rise to similar subsurface cavities in coal-mined areas (Bell, 1996).

\subsection{Quantifying tailings tonnage and erosion from the El Roble dam tailings}


The total volume of tailings filling the El Roble valley (Fig. 6) is about $370,000 \mathrm{~m}^{3}$, which for a bulk density of $1.6 \mathrm{~g} \mathrm{~cm}^{-3}$ yields a total and original tonnage of 592,000 MT; these materials do not account for those that were lost during ongoing erosion because the TIN used for the quantification already had the gullied topography (PNOA, 2009). An estimation of the removal follows. Figure 11 shows the two TINs generated for the tailings dam topography: (A) as of 1968, reconstructed following the procedure explained in the material and methods section; (B) as of 2009, from the 2009 LIDAR point cloud (PNOA, 2009). The difference between both TINs is about $3500 \mathrm{~m}^{3}$. The density of the eroded material is $1.6 \mathrm{~g} \mathrm{~cm}^{-3}$. Therefore, the total sediment eroded is volume times density, which yields 5600 MT. Considering the area of the dam, the resulting erosion rate (1968-2009) is around $150 \mathrm{Mg}$ (MT) $\mathrm{ha}^{-1} \mathrm{y}^{-1}$. This means a mean annual lowering rate, for the whole dam, of $9.3 \mathrm{~mm} \mathrm{y}^{-1}$ (about $1 \mathrm{~cm} \mathrm{y}^{-1}$ ). The mean annual lowering rate has only the purpose of offering an idea of the magnitude of the erosion process because there is no such homogeneous lowering but erosion in gullies.

There degree of uncertainty at the reconstructed original topography of the tailings dam as of 1968 is unknown, as it was not possible to verify, in the field, if the identified points of the head of the outslopes were in their original position or if they had been eroded. Additionally, some of the points marking the outslopes' toes showed sedimentation. Another limitation for making this quantification is the resolution of the LIDAR data of PNOA (2009), 0.5 points $\mathrm{m}^{-2}$, which is not considered to be detailed enough to represent the complex gullied topography developed in the tailings dam. Therefore, a higher resolution would have been needed in order to get more accuracy. However, ground conditions at the Mazarrón tailings sites make the use of Terrestrial Laser Scanner (TLS) very difficult.

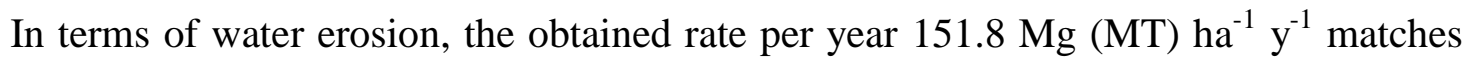
very well with typical values of water erosion directly measured at mined areas, commonly 
above $100 \mathrm{Mg} \mathrm{ha}^{-1} \mathrm{y}^{-1}: 93 \mathrm{Mg} \mathrm{ha}^{-1} \mathrm{y}^{-1}$ (Haigh, 1979); 160-180 $\mathrm{Mg} \mathrm{ha}^{-1} \mathrm{y}^{-1}$ (Goodman and Haigh, 1981); 116 and $203 \mathrm{Mg} \mathrm{ha}^{-1} \mathrm{y}^{-1}$ (West and Wali, 1999); $425 \mathrm{Mg} \mathrm{ha}^{-1} \mathrm{y}^{-1}$ (So et al., 2002); among others. However, if this value is within the order of magnitude of what can be expected for mined sites in terms of 'pure water soil erosion'it is extraordinary high for sediments with exceptionally high metal content.

\subsection{Interpretation of the erosive characteristics of the tailings and hydrological connectivity as a key factor for environmental effects and risk potential}

The El Roble mine tailing deposits filled the head of a small valley, formerly a tributary of the Las Moreras wadi. The analysis of landforms at these abandoned tailings and at its surroundings demonstrates that there is a high geomorphic activity (and therefore instability) in this minescape. We interpret that these predominant erosive characteristics reflect the geomorphic work to reestablish a new steady state between the new landforms (tailings accumulation) and the site environmental conditions (Schumm and Rea, 1995); this fact has important environmental implications. Thus, the main concern of having a dense network of deep gullies on tailings deposits is that harmful heavy metals and metalloids — such as lead or arsenic- are being dispersed into the environment (Oyarzun et al., 2011); this is because gullies transmit ephemeral flows that are very efficient moving sediments off-site. Therefore, this entire geomorphic system works toward the evacuation of sediments from the mined areas to Las Moreras wadi, mobilizing high amounts of sediments within the area. The main environmental effects and risk potential are then entirely related with the hydrological connectivity of the affected elements of this landscape (Fig. 12).

Part of the eroded material is retained in the sectors that lack a connection with the Las Moreras stream, being sedimented within small endorheic basins within the mine. So far, only 
the slopes of two tailings' dams in the El Roble area - but also other areas of the San Cristóbal-Perules mined site- are hydrologically connected with the Las Moreras fluvial system. That causes, during intense storms, flash floods at Las Moreras that are loaded with sediments coming from this mined site (Figs. 2 and 12). As this geomorphic system evolves, new areas of the minescape connect with the Las Moreras wadi. The process of a progressive increase of mined areas hydrologically connected with Las Moreras fluvial system is caused by the process in which gullies of the upland surfaces ('tailing platforms') expand on undissected surfaces by headcutting (Fig. 13).

\section{Lessons from a minescape: the search for environmentally sound solutions}

The Mazarrón minescape has an invaluable educational value because it allows identification of a high diversity of erosional and sedimentary landforms in a reduced area (Petersen, 2002). Thus, a broad catalogue of typical landforms of semiarid erosive areas (related with water erosion and mass movements) can be recognized in short walking distances in the surroundings of the El Roble tailings dam: pedestals, sheet-erosion-made landforms, different types of rills and gullies, badland-like terrains, braided sand-bed channels, alluvial cones, earth slides, earth falls and topples, and different kinds of collapses. The catalogue of landforms and related active geomorphic processes that is provided here is novel for a minescape of a semiarid region. If this information is linked to their meaning in terms of geomorphic instability, then we may get a picture on the foreseeable future of tailing dams once the mine installations are decommissioned. As already stated in terms of geomorphic instability, gullies are a clear sign of severity of the water erosion process. 
Covering the tailings, with either geotextiles or soil may prove useless in the long term. A tailings deposit should be stable not in terms of a few years or decades (best case scenario at present) but for centuries. In this regard, perhaps a different and more powerful approach is needed, for example geomorphic reclamation, involving the stabilization of this anthropic landscape. For instance, the New Mexico Mining and Minerals Division specifically recognizes this fact in its legal requirement for mining reclamation (NMMMD, 2010). The GeoFluv method (Bugosh, 2000, 2007) for geomorphic reclamation replicates factors of natural-stable landscapes such as drainage density, slope shape, channel profiles and sinuosity, among others. The philosophy behind this approach is simple: if a deposit is bound to physically evolve (along decades or centuries) as erosion carves it, why then not accelerate the process using bulldozers and backhoe excavators to create a stable new surface? In other words, a mature landscape can be obtained almost instantly; this has many advantages, including minimizing the erosion to very small levels. Thus, this dynamic geomorphic procedure tackles most of the erosion-related problem because it essentially reproduces the natural landform evolution to the mature stage, resulting in stable slopes and channels in balance with the local environmental conditions (Martín-Duque et al., 2010). This reflection means also that the hydrological connectivity of minescapes with their surrounding is not the problem per se. Actually, the aim of a geomorphic reclamation is to get a hydrological connectivity between the restored mined lands and the downstream watersheds, but guaranteeing not having a higher erosion than that of the surroundings. The problems with hydrological connectivity arise when the mine deposits are highly unstable and have harmful heavy metals or metalloids, as is the case in the Mazarrón area.

Geomorphic reclamation projects have been and are being designed and constructed worldwide at coal mines and quarries. However, this method has not been proven yet at tailing deposits. Therefore, the key question is: can geomorphic reclamation provide sound 
solutions for the stabilization of tailing deposits? The first limitation is the process by which they are accumulated: the fact that a slurry mixture of mineral particles and water that comprise the tailings need to be accumulated 'upstream' in dams prevents us from building stable landforms from the beginning, as it is made in coal mines and quarries. However, tailing ponds could also be designed with an irregular footprint and built up in lifts to a GeoFluv design. However, the standard practice is to design very simple, linear shapes. In addition to building irregular tailing ponds, a reclamation solution would be transforming the valley fill of the tailings dam, once dry, into the head of a watershed with a dendritic drainage fluvial network (Bugosh, 2000). The advantages of such procedures relate to the fact that the geomorphic reclamation allows less water to infiltrate, moving water through the fill at a faster rate, but without being erosive, having less storage volume, and lower pore pressure buildup. In this regard, Russell et al. (2014) found that the geomorphic design slope stability analysis yielded much higher factors of safety compared to traditional valley fills (over 2.0 compared to 1.3). The reason for these high slope stability factors of safety is that the geomorphic designs have shallow slopes and beneficial drainage (surface and internal), avoiding an increase in pore pressure that often triggers slope instability. Additionally, Quaranta et al. (2013) found out that higher water velocities (decreased residence times) and less water storage occur through mine spoil reclaimed according to the geomorphic fill design. And shorter hydraulic transit times through the spoil result in lower ionic concentrations in discharge water. In short, the beneficial is not only in terms of stability, but also about reducing pollution to the environment. Geomorphic stability gained using the GeoFluv method has been empirically proven for more than a decade in some mines from New Mexico (USA) (Bugosh and Epp, 2014). Additionally, present models allow predictions for the behavior of these tailings deposits in their traditional way of building (dams) or those that have been geomorphically reclaimed. The most remarkable example is the SIBERIA 
model, which can predict thousands of years of change in the shape of a landform, broadly tested for this purpose at minescapes (Willgoose and Riley, 1998; Evans et al., 2000; Hancock and Turley, 2006).

However, the risks of significant earth-moving tailing deposits with high metal contents need to be evaluated (see for example Oyarzun et al., 2013). Geomorphic reclamation of tailing deposits should (whatever the circumstances are) be accompanied by chemical stabilization, covering the area with new soils, and revegetation (e.g., Johnson and Hallberg, 2005). This could be achieved in the following way: (i) adding carbonate to the tailings material (if pyrite is present in the tailings) while the new landscape is being built during geomorphic reclamation works (e.g., GeoFluv method); (ii) covering the new surface with a thick, compacted, clay-rich protective layer to impede gaseous diffusion of oxygen to the interior of the deposit; and (iii) covering the protecting layer with topsoil for planting local plant species. On the contrary, if the tailings deposit is left as it is, the rainwater will pond and eventually will percolate to the interior, as shown at Mazarrón and other abandoned tailing deposits around the world. On the other hand, the use of a topsoil rich in macropores will do little to impede gaseous diffusion of oxygen to the interior (e.g., Dziejowski et al., 1997) and therefore oxidation of pyrite, generation of sulphuric acid, and eventually leaching of heavy metals. Let us be clear on this matter, no topsoil (alone) will prevent erosion and this might prove to be a very shortsighted solution because in the end, if a landform is unstable, erosion will carve it sooner or later. In this regard, Mazarrón provides an excellent example of the dangers that erosion may pose in a few decades (Fig. 2).

Covering the tailings with topsoil and doing some gardening might be cheaper today (for a mining company) but far more expensive (for the society) in the end. For example, the closing and remediation of the old Faro mine ( $\mathrm{Pb}-\mathrm{Zn})$ site in Yukon (Canada) will cost about $\$ 700$ million (Canadian dollars) (Faro Mine Remediation Project, 2011) to the federal 
government of Canada; constant monitoring of the area will take decades if not centuries. Metals and minerals are needed by the society, therefore the key issue here is not whether we should keep mining or not, but how we do it and, in particular, 'what' we leave behind after mining has ceased. If we search for truly sustainable schemes, then mining will not be a liability for future generations, and this can be achieved implementing real long-term reclamation policies. In our opinion, whatever the long-term policy is, it should include a dynamic geomorphic approach involving restoration of the mine wastes through landform design, thus searching for stable slopes and channels in balance with the local environmental conditions.

The Mazarrón example shows us how 'youthful' landforms created by humans (tailing deposits in this case) can be subjected to a fast and intense superficial dynamism while trying to reach a mature character. Thus, erosion, transport, and sedimentation processes adapt to the environmental conditions in which they are being developed (e.g., Graf, 1977). Therefore, reclamation works should take into account the mature landforms, thus replicating the natural landscapes that have been subjected to thousands of years of erosive actions, including extreme events (storms, earthquakes, etc.). This geomorphological approach (in combination with mineralogical, geochemical, and geophysical studies) emerges as the wisest course of action to evaluate the actual risks related to tailings deposits. However, to our best knowledge this is not a common practice, neither in active nor in decommissioned tailing dams.

\section{Conclusions}

The study of landforms within a minescape such as the one provided by San CristóbalPerules, in the Mazarrón district, provides some useful lessons for geomorphological and 
environmental studies. On the one hand the site has a powerful educational value in that within a relatively small area a myriad of landforms can be observed and properly understood. Some of these forms are truly small-scale representations of much larger features that cannot be observed at once in natural landscapes because of their much larger size. Meters (not kilometres) are the observational scale at San Cristóbal-Perules. The study also reveals the importance of combining chemical, mineralogical, and geomorphological studies. Although no specific geochemical or mineralogical studies were conducted during research, previous works by some of the authors contributed to a better understanding of key phenomena at San Cristóbal-Perules, such as piping and removal of forms during complex hydrated sulphate dissolution. Although no specific monitoring of the site has been carried out, successive visits to Mazarrón during the last 10 years have allowed an informal follow up of the continuous erosion of the tailing deposits, including the observation of stormy episodes such as that of 2008 (Fig. 2). On the other hand, from an environmental perspective, the study of San Cristóbal-Perules provides a world-class example of what erosion can do to tailings deposits ('heavy metal reservoirs') in relatively short periods of time. From our experience in South America and Europe, neither the operators (mining companies) nor the regulators (political authorities) have a grasp on what the geomorphic evolution of tailings deposits through time can bring. Human beings move and think in an entirely different timeframe to that of geology. Thus, most of the solutions proposed in environmental impact assessment reports (including mine closure plans) are not bound to last more than a few decades (some do not survive after a few years). As shown here, it does not take millennia but mere decades to induce strong erosion and removal of tailing deposits, thus the question is what we should do about them beyond the typical planting of some aesthetic (but allochthonous) grasses, shrubs, and trees on top of the wastes (with or without the installation of engineered soil covers). In this regard, our proposal involves restoration of these deposits through landform design, looking for 
stable mature landscapes that withstand erosion much more easily. If the wastes contain metal sulphides, then chemical neutralization (e.g., with pellets of $\mathrm{CaCO}_{3}$ ) should accompany the process. Once all of this has been accomplished, then we may introduce the proper vegetation cover, i.e., using local, resilient plant species.

\section{Acknowledgements}

This study was funded by the Research Projects CGL2010-21754-C02-01 and CTM201233918 (Spanish Ministry of Science and Technology, and Ministry of Economy), and Grant JAE-Predoc of (CSIC). The authors want to thank Carlos de Andrés for his help with the erosion quantification of the tailings dam. We are grateful to four anonymous reviewers and to Editor Richard A. Marston for a very careful and professional review and editing of our work, which has led to a significant improvement of the original manuscript.

\section{References}

Acosta, J.A., Martínez-Martínez, S., Martínez-Pagan, P., Zornoza, R., Carmona, D.M., Faz, A., 2011. Estudio de estabilidad en depósitos de lodos del Distrito Minero de Mazarrón (SE España): Riesgos potenciales sobre la Rambla de Las Moreras. Bol. Geol. Min. 122, 145-160.

Bell, F.G., 1996. Dereliction: Colliery spoil heaps and their rehabilitation. Environ. Eng. Geosci. 2, 85-96.

Beullens, J., Van de Velde, D., Nyssen, J., 2014. Impact of slope aspect on hydrological rainfall and on the magnitude of rill erosion in Belgium and northern France. Catena 114, 129-139. 
Brice, J.C., 1966. Erosion and deposition in the loess-mantled Great Plains. Medicine Creek drainage basin, Nebrasca. US Geol. Surv. Prof. Pap. 352H, 255-335.

Bugosh, N., 2000. Fluvial geomorphic principles applied to mined land reclamation. In: OSM Alternatives to Gradient Terraces Workshop, January 2000. Office of Surface Mining, Farmington, NM, without page numbers.

Bugosh, N., 2007. Technology utilizes nature's design. Sustainable Land Development Today, February, 16-17.

Bugosh, N., Epp, E., 2014. Evaluating Sediment Production from Watersheds at La Plata Mine. In: Advances in Fluvial Geomorphic Reclamation at Coal Mines, 20-22 May 2014, Albuquerque, New Mexico, U.S. Department of the Interior, Office of Surface Mining, Washington, D.C., without page numbers.

Campbell, I.A., 1997. Badlands and badland gullies. In: Thomas, D.S.G. (Ed.), Arid Zone Geomorphology. Process, Form and Change in Drylands, 2nd Edition. Belhaven Press, London, pp. 261-291.

Chambers, B., Plewes, H., Pottie, J., Murray, L., Burgess, A., 2003. Water recovery from a mine in the Atacama Desert. In: Water in Mining - 2003, October 13-15, 2003, Brisbane, Australia, http://www.infomine.com/library/publications/docs/Chambers2003.pdf

CNIG, 2014. Centro Nacional de Información Geográfica, Fototeca Virtual (virtual photographic library). Instituto Geográfico Nacional, Ministerio de Fomento (http://www.fototeca.cnig.es/ (accesed February 2014).

Crespo, E., Lillo, J., Oyarzun, R., Cubas, P., Leal, M., 2013. The Mazarrón basin, SE Spain: a study of mineralization processes, evolving magmatic series, and geothermal activity. International Geol. Rev. 55, 1978-1990.

Dziejowski, J.E., Rimmer, A., Steenhuis, T.S., 1997. Preferential movement of oxygen in soils? Soil Sci. Soc.Am. J. 61, 1607-1610. 
ESRI, 2013. ArcGIS. 10.2.2.

Evans, K.G., Loch, R.J., 1996. Using the RUSLE to identify factors controlling erosion rates of mine soils. Land Degrad. Dev. Rehabil. 7, 267-277.

Evans, K.G., Saynor, M.J., Willgoose, R., Riley, S.J., 2000. Post-mining landform evolution modelling: 1. Derivation of sediment transport model and rainfall-runoff model parameters. Earth Surf. Processes Landf. 25, 743-763. doi:10.1002/10969837(200007)25:7〈743::AID-ESP95〉3.0.CO;2-0

Faro Mine Remediation Project, 2011. Reference: Frequently Asked Questions - The Environment at the Mine Site. http://www.faromine.ca/reference/faq.html (accessed August 2014).

García-Rizo, C., Martínez-Sánchez, J., Pérez-Sirvent, C., 1999. Environmental transfer of zinc in calcareous soils in zones near mining sites with semi-aridic climate. Chemosphere 39, 209-227.

Goodman, J.M., Haigh, M.J., 1981. Slope evolution on abandoned spoil banks in Eastern Oklahoma. Phys. Geogr. 2(2), 160-173.

Graf, W., 1977. The rate law in fluvial geomorphology. Am. J. Sci. 27,178-191.

Haigh, M.J., 1979. Ground retreat and slope evolution on regraded surface-mine dumps, Waunafon, Gwent. Earth Surf. Processes 4, 183-189. doi:10.1002/esp.3290040208

Haigh, M.J., 1980. Slope retreat and gullying on revegetated surface mine dumps, Waun Hoscyn, Gwent. Earth Surf. Processes 5(1), 77-79. doi:10.1002/esp.3760050108

Hancock, G.R., Turley, E., 2006. Evaluation of proposed waste rock dump designs using the SIBERIA erosion model. Environ. Geol. 49, 765-779.

Hancock, G.R., Loch, R.J., Willgoose, G.R., 2003. The design of postmining landscapes using geomorphic principles. Earth Surf. Processes Landf. 28, 1097-1110. doi:10.1002/esp.518 
Hooke, R., Martín Duque, J.F., Pedraza, J., 2012. Land transformation by humans. GSA Today 22(12), 4-10. doi: 10.1130/GSAT151A.1.

IAG 2014. Web site of the International Association of Geomorphologists, IAG. http://www. geomorph.org/Accessed April 19, 2014.

IDERM, 2009-2014. Mapa digital de suelos de la Región de Murcia (recurso online). http://www.cartomur.com/servicios/wms_10_2.htm. (accessed February 2014).

James, L.A., 2005. Sediment from hydraulic mining detained by Englebright and small dams in the Yuba basin. Geomorphology 71, 202-226. doi:10.1016/j.geomorph.2004.02.016

Johnson, D.B., Hallberg, K.B., 2005. Acid mine drainage remediation options: a review. Sci. Total Environ. 338, 3-14.

Kawatra, S.K., 2011. Fundamental principles of froth flotation. In: Darling, P. (Ed.), SME Mining Engineering Handbook. Society for Mining, Metallurgy, and Exploration, Englewood (CO), pp. 1517-1532.

Langedal, M., 1997. The influence of a large anthropogenic sediment source on the fluvial geomorphology of the Knabeåna-Kvina rivers, Norway. Geomorphology 19, 117-132. PII: S0169-555X(96)000426

Lecce, S.A., Pavlowsky, R.T., 2014. Floodplain storage of sediment contaminated by mercury and copper from historic gold mining at Gold Hill, North Carolina, USA. Geomorphology 206, 122-132. http://dx.doi.org/10.1016/j.geomorph.2013.10.004

Macklin, M.G., Brewer, P.A., Hudson-Edwards, K.A., Bird, G., Coulthard, T.J., Dennis, I.A., Lechler, P.J., Miller, J.R., Turner, J.N., 2006. A geomorphological approach to the management of rivers contaminated by metal mining. Geomorphology 79, 423-447. doi:10.1016/j.geomorph.2006.06.024

Manteca, J.I., López García, J.A., Oyarzun, R., Carmona, C., 2014. The beach placer iron deposit of Portman Bay, Murcia, SE Spain: the result of 33 years of tailings disposal 
(1957-1990) to the Mediterranean seaside. Miner. Deposita 49(6), 777-783. doi 10.1007/s00126-014-0511-x.

Martín-Duque, J.F., Sanz, M.A., Bodoque, J.M., Lucía, A., Martín-Moreno, C., 2010. Restoring earth surface processes through landform design. A 13-year monitoring of a geomorphic reclamation model for quarries on slopes. Earth Surf. Processes Landf. 35, $531-548$.

Moreno-de las Heras, M., Merino-Martín, L., Nicolau, J.M., 2009. Effect of vegetation cover on the hydrology of reclaimed mining soils under Mediterranean-Continental climate. Catena 77, 39-47.

NMMMD, 2010. A Method for the Evaluation of Compliance with the Approximate Original Contour Requirements of CSMC RULE 19.8. NMAC. New Mexico Mining and Minerals Division, Santa Fe.

Nyssen, J., Vermeerch, D., 2010. Slope aspect affects geomorphic dynamics of coal mining spoil heaps in Belgium. Geomorphology 123, 109-121. doi:10.1016/j.geomorph.2010.07.004

Oyarzun, R., Márquez, A., Ortega, L., Lunar, R., Oyarzún, J., 1995. A late Miocene metallogenic province in southeast Spain: atypical Andean-type processes on a smaller scale. Trans. Inst. Min. Metall. B 104, 197-202.

Oyarzun, R., Lillo, J., López-García, J.A., Esbrí, J.M., Cubas, P., Llanos, W., Higueras, P., 2011. The Mazarrón $\mathrm{Pb}-(\mathrm{Ag})-\mathrm{Zn}$ mining district (SE Spain) as a source of heavy metal contamination in a semiarid realm: Geochemical data from mine wastes, soils, and stream sediments. J. Geochem. Explor. 109, 113-124.

Oyarzun, R., Manteca Martínez, J.I., López García, J.A., Carmona, C., 2013. An account of the events that led to full bay infilling with sulfide tailings at Portman (Spain), and the 
search for "black swans" in a potential land reclamation scenario. Sci. Total Environ. $454-455,245-249$.

Panizza, M., 1996. Environmental Geomorphology. Elsevier, Amsterdam.

Pantaleón-Cano, J., Yll, E.I., Pérez-Obiol, R., Roure, J.M., 2003. Palynological evidence for vegetational history in semi-arid areas of the western Mediterranean (Almería, Spain). Holocene 13, 109-119.

Petersen, J.F., 2002. The role of roacuts, quarries and other artificial exposures in geomorphology education. Geomorphology 47(2-4), 289-301.

PNOA, 2009. Plan Nacional de Ortofotografía Aérea, LIDAR y Ortofotos de Castilla LaMancha, vuelo de 2009. Instituto Geográfico Nacional, Ministerio de Fomento (http://www.ign.es/PNOA/ (accessed December 2013).

Quaranta, J.D., Hopkinson, L., Ziemkiewicz, P., 2013. Comparison of groundwater seepage modeling in approximate original contour and geomorphic valley fill design. In: Craynon, J.R. (Ed.) Environmental Considerations in Energy Production, Society for Mining, Metallurgy, and Exploration (SME), Englewood, CO, pp. 246-254.

Riley, S.J., 1995. Geomorphic estimates of the stability of a uranium mill tailings containment cover, Nabarlek, NT, Australia. Land Degrad. Rehabil. 6, 1-16.

Rivas, V., Cendrero, A., Hurtado, M., Cabral, M., Giménez, J., Forte, L., del Río, L., Cantú, M., Becker, A., 2006. Geomorphic consequences of urban development and mining activities; an analysis of study areas in Spain and Argentina. Geomorphology 73, 185 206.

Russell, H., DePriest, N., Quaranta, J.D., 2014. Stability analysis comparison of conventional valley-fill to geomorphic landform designs. Trans. Soc. Min. Metall. Expl. (in press).

Schumm, S.A., Rea, D.K., 1995. Sediment yield from disturbed earth systems. Geology 23(5), 391-394. 
So, H.B., Yatapange, K., Horn, C.P., 2002. Mine-Erosion: an integrated erosion and landscape design package for monitoring and modeling erosion from steep hillslopes on minespoils. 12th ISCO Conference, Beijing, pp. 36-41.

Taylor, M.P., Kesterton, R.G.H., 2002. Heavy metal contamination of an arid river environment: Gruben River, Namibia. Geomorphology 42, 311-327. PII: S0169$555 X(01) 00093-9$

Torri, D., Borselli, L., 2003. Equation for high-rate gully erosion. Catena 50, 449-467.

West, T.O., Wali, M.K., 1999. A model for estimating sediment yield from surface-mined lands. Int. J. Surf. Min. Reclamat. Environ 13(3), 103-109.

Willgoose, G., Riley, S., 1998. The long-term stability of engineered landforms of the Ranger Uranium Mine, Northern Territory, Australia. Application of a catchment evolution model. Earth Surf. Processes Landf. 23, 237-259. doi:10.1002/(SICI)10969837(199803)23:3〈237::AID-ESP846〉3.0.CO;2-X

WISE, 2014. Tailings dam safety. http://www.wise-uranium.org/indexm.html 


\section{List of figures}

Fig. 1. (A) The Mazarrón district at the Iberian Peninsula. (B) Digital elevation model for Mazarrón displaying major physiographic features. (C) Climatic diagram. (D) Regional geology of Mazarrón (after Crespo et al., 2013), displaying major mining sites and location of towns. The study area is located at the San Cristóbal-Perules site.

Fig. 2. (A) Severe erosion and removal of oxidized old tailing deposits at San CristóbalPerules abandoned mining site (Mazarrón mining district). (B) Removal of oxidized tailings at Mazarrón during a stormy episode on 8 May 2008; part of the tailings materials (on the left) were being transported to the Rambla de las Moreras stream (on the right), and from there to the Mediterranean Sea some $4 \mathrm{~km}$ downstream.

Fig. 3. Digital elevation model of the main land features that layout the framework of this research. (1) Built area of the Mazarrón town. (2) San Cristóbal-Perules mining area. (3) Las Moreras stream (rambla). (4) Studied tailing deposits. Data source: LIDAR data from the files 648-4164, 648-4162, 646-4162, 646-4164 (PNOA 2009). Coordinate system: UTM 30N, DATUM: ETRS89.

Fig. 4. Oblique aerial photograph of the San Cristóbal-Perules mining area showing the existing landscape in 1968 (photograph by Paisajes Españoles S.A.). The white circle is El Roble dam, showing the original morphology of the tailing deposits: (1) terraced (benches plus outslopes) tailings dam; (2) pond area with tailings slurry/sediments. 
Fig. 5. (A) General view of old and modern tailing deposits (OTD and MTD), ephemeral pond $(E P)$, and the surrounding hills. The modern tailings deposits have been covered in recent years by the old ones, see for example how a mudflow (*) originating in an Old Tailing Deposit (OTD) covers modern tailings (MTD). (B) General view showing striking differences in plant cover between the tailings deposits (no vegetation cover), waste rock deposits (WRD, minor vegetation cover), and the surrounding hills (normal vegetation cover). The shape and size of the ephemeral pond $(E P)$ changes every now and then, which explains why its position does not match perfectly in (A) and (B). (C) Perennial grasslands of esparto grass (Stipa tenacissima) with Launaea arborescens, covering the hillslopes. (D) Bushes of Salsola oppositifolia (salao borde), Capparis spinosa (caper bush) and Launaea arborescens on dirty road alongside old tailing deposits. (E) Salsola oppositifolia growing on top of waste rock deposits. (F) Shrublands composed by thymes (Thymus sp.), Dianthus broteri, and grasses on the slopes facing NW. Sligthly displaced to the right at the base of the main picture (B). See also (A).

Fig. 6. Two- and three-dimensional representation of El Roble valley with and without its tailings dam valley fill. (A.1) Two-dimensional aerial photograph of 1956 (without valley fill), downloaded from the virtual photographic library of the CNIG (2014). (B.1) Orthophoto of 2009 (with valley fill and gullied dam) (PNOA, 2009). (A.2) Three-dimensional view without valley-fill. (B.2) Three-dimensional view with valley fill and gullied dam. For the three-dimensional images, see text within manuscript for a detailed explanation (Coordinate system: UTM 30N, DATUM: ETRS89).

Fig. 7. Tailing mine deposits of El Roble, which are the focus of this paper. (A) Oblique aerial photograph as of 1968 (Paisajes Españoles S.A.). (B) Orthophotograph raised with MDE 
elaborated from LIDAR data of 2009 (data source: Ortophotograph, sheet 976 and LIDAR from the file 646-4164; PNOA, 2009. Coordinate system: UTM 30N, DATUM: ETRS89).

Fig. 8. Surveying the El Roble dam with a GPS Leica 1200 instrument while identifying remnants of the original breaklines. The surveyor is standing at the remnant of a former bench.

Fig. 9. Catalogue and classification of the main landforms denoting current geomorphic activity at the surroundings of the El Roble tailings dam. The numbers correspond with those described within the text. See text for detailed explanations of each landform.

Fig. 10. Location of the photos that constitute the catalogue of landforms of Fig. 7.

Data source: Ortophotograph sheet 976; PNOA, 2009. Coordinate system: UTM 30N; DATUM: ETRS89.

Fig. 11. Triangular irregular networks (TIN) of the tailings dam of El Roble. (A) Reconstructed, original topography as of 1968 (see text for detailed explanation). (B) Eroded topography of the dam as of 2009 (data source: LIDAR from the file 646-4164; PNOA, 2009. Coordinate system: UTM 30N, DATUM: ETRS89).

Fig. 12. Representation of the hydrological connectivity between the eroded tailings dams and the Las Moreras Rambla (river). Data source: Ortophotograph sheet 976 and LIDAR from the files 648-4164, 648-4162, 646-4162, 646-4164; PNOA, 2009. Coordinate system: UTM 30N, DATUM: ETRS89. 
Fig. 13. Edge of the El Roble tailings dam. The slope toward the right of the image is the tailings dam, formerly the only element hydrologically connected with Las Moreras fluvial system. As geomorphic instability progresses, the platform toward the right of the image (that was the beach area of sedimentation behind the tailings dam), originally forming a closed basin, connects with the Las Moreras fluvial system by gullies' headcutting (see gullies at the lower half of the image). 


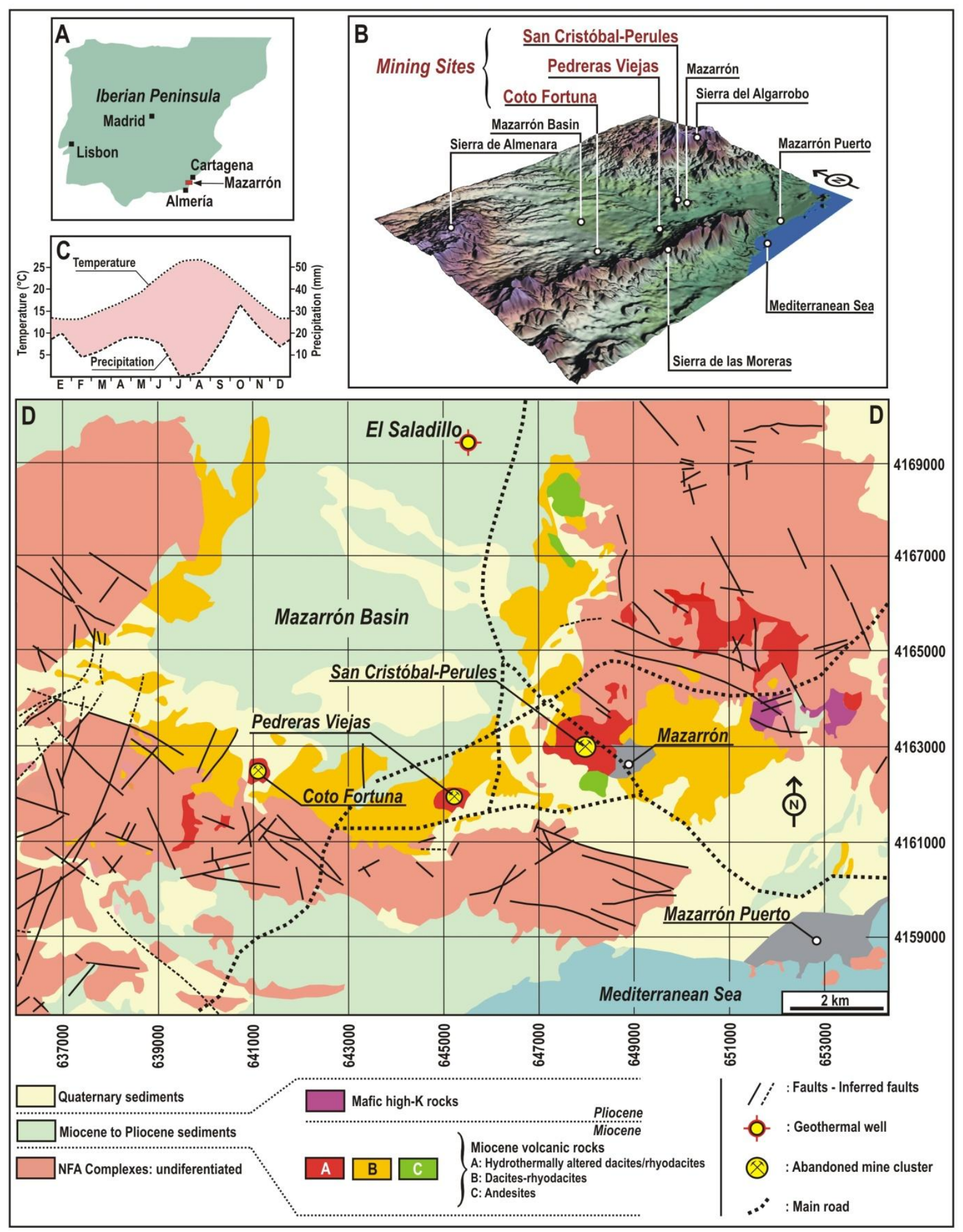

Figure 1 
A

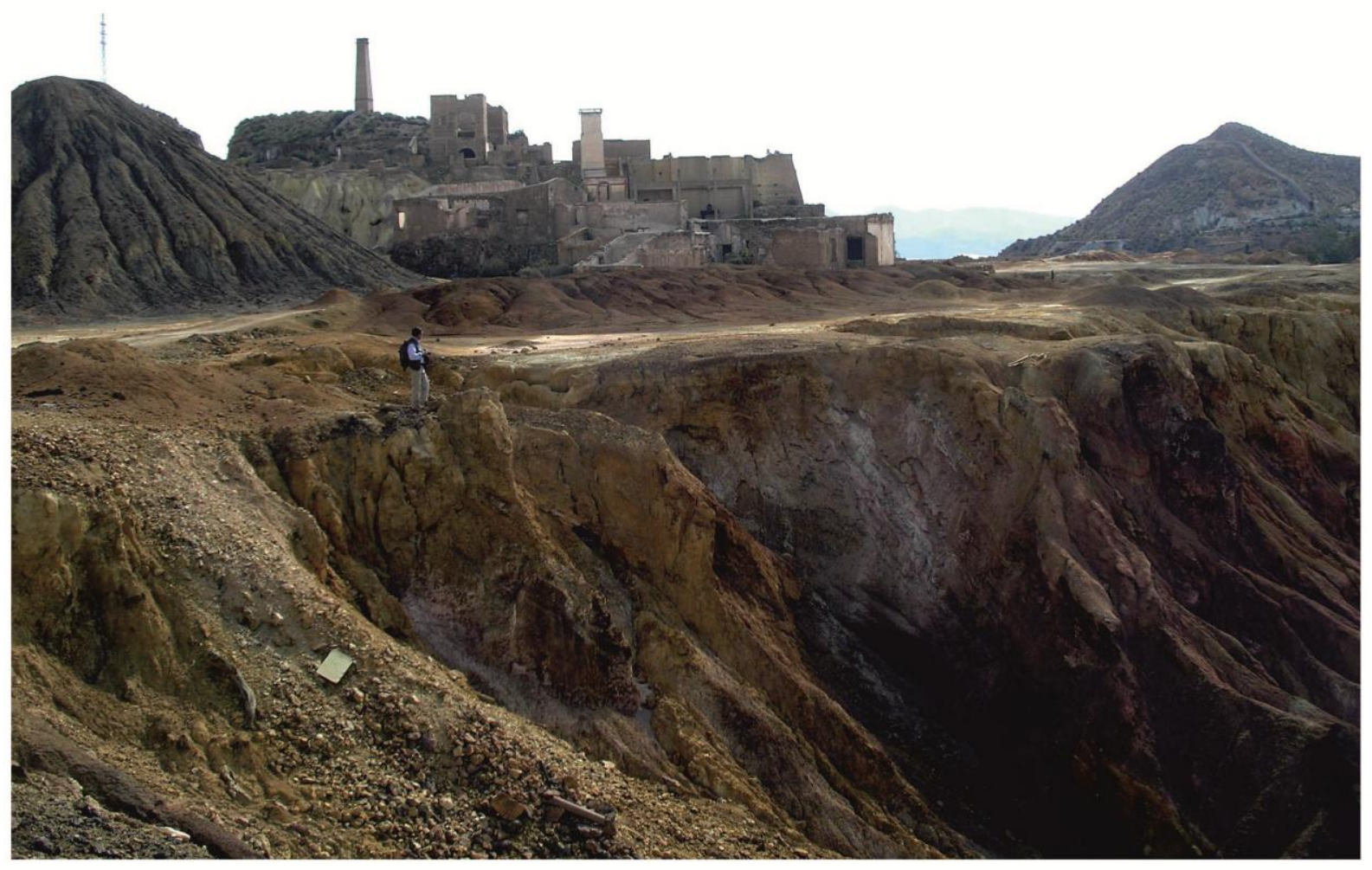

B

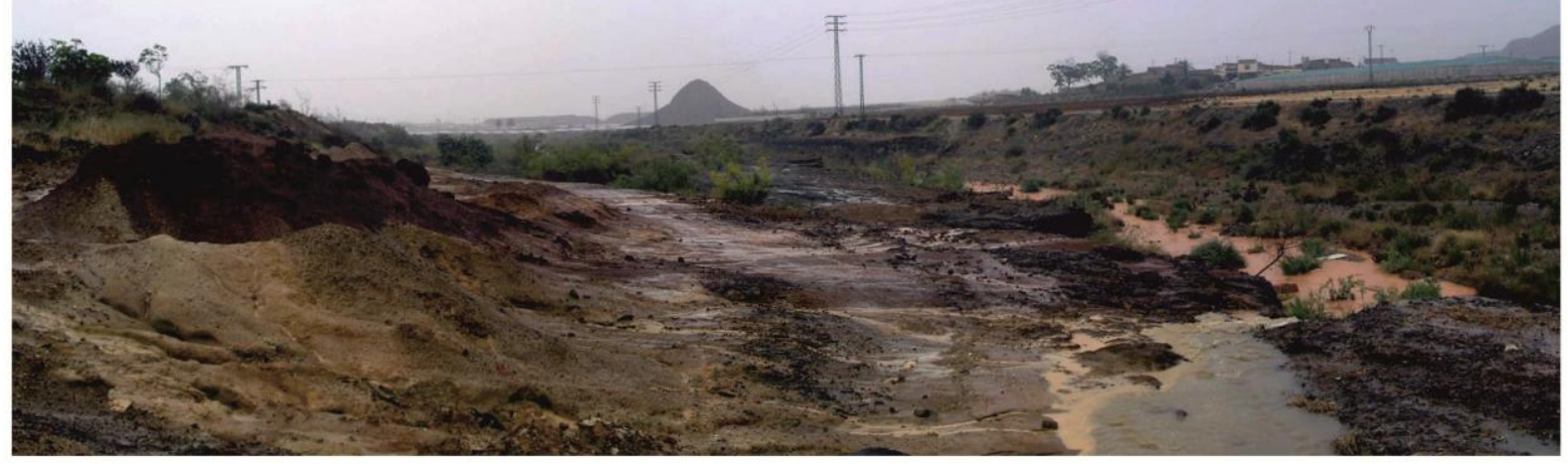

Figure 2 


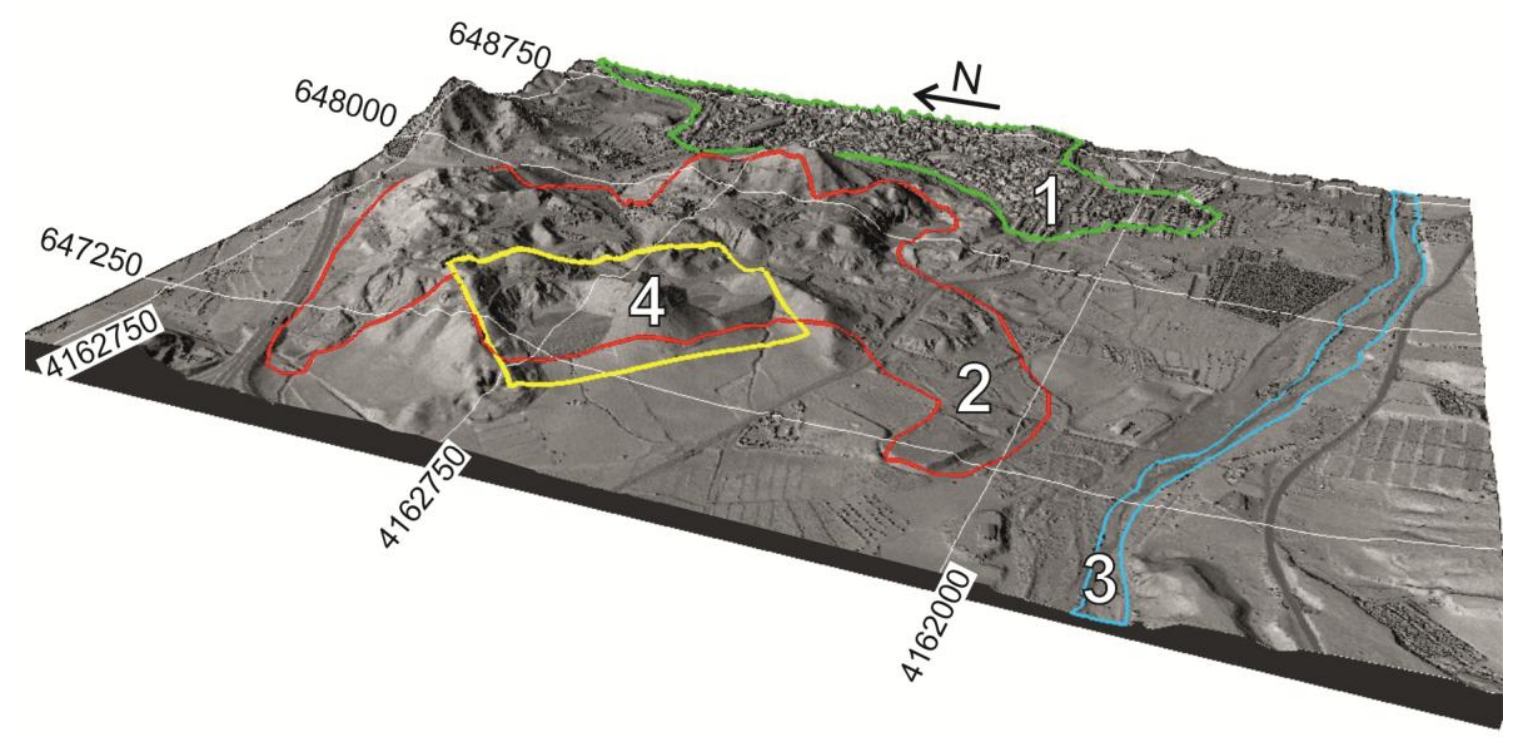

Figure 3 


\section{ACCEPTED MANUSCRIPT}

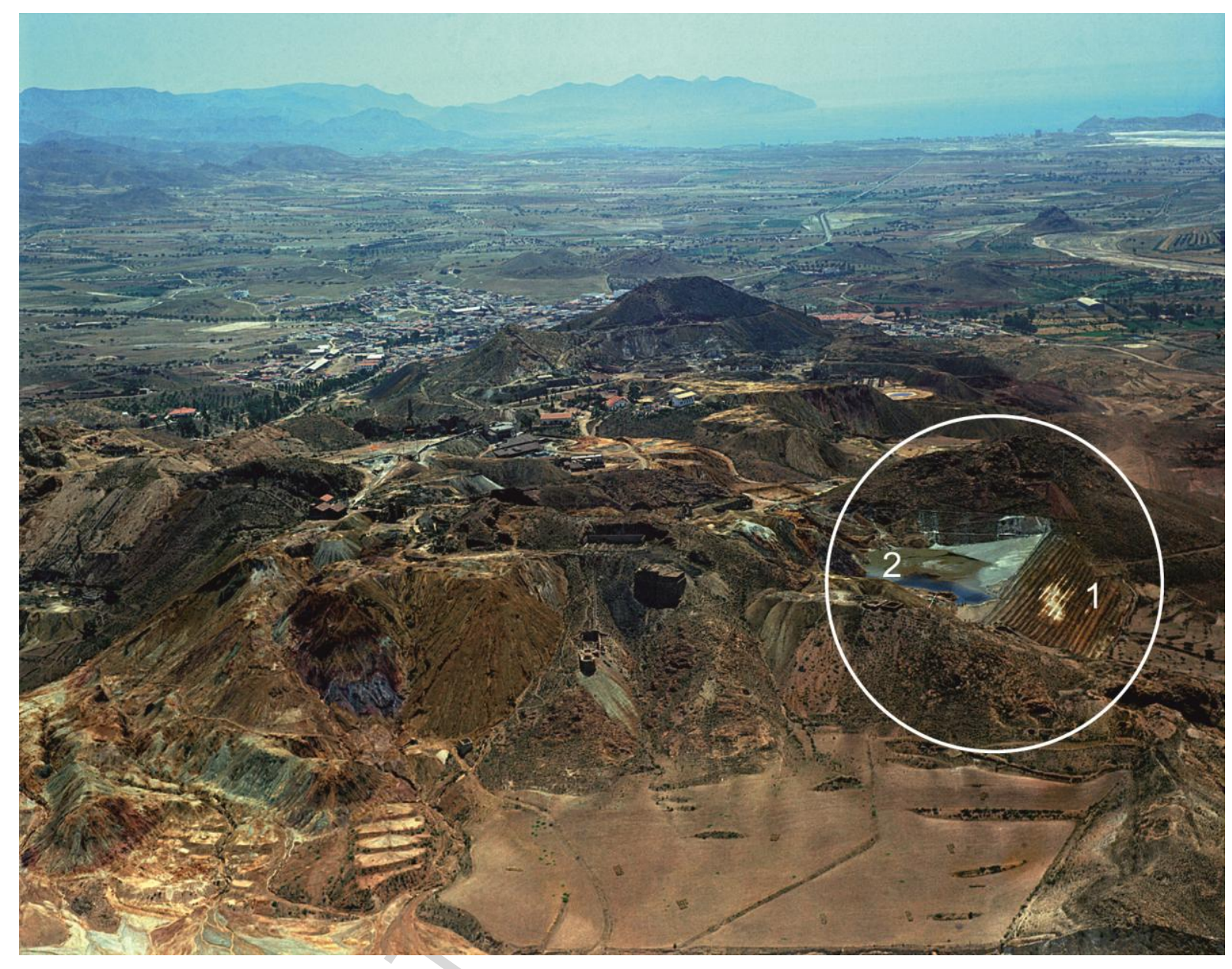

Figure 4 


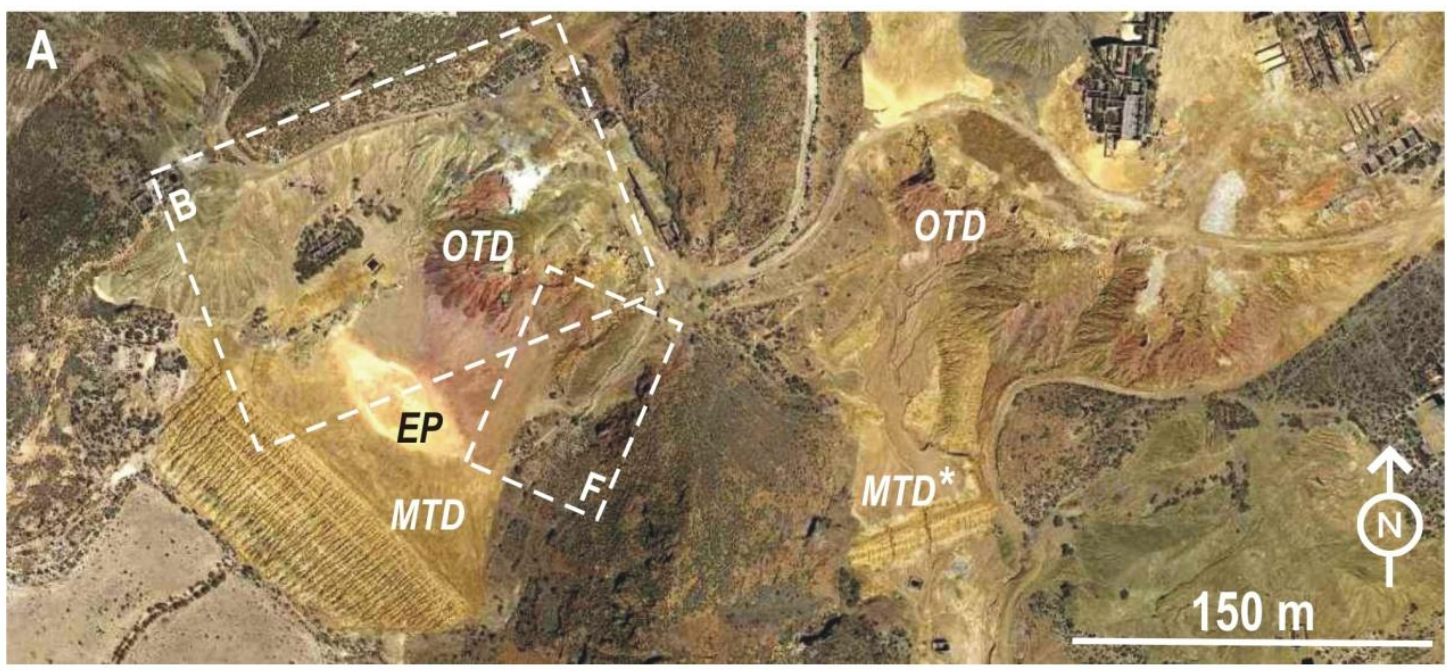

\section{B Perennial grasslands of esparto grass (Stipa tenacissima)}
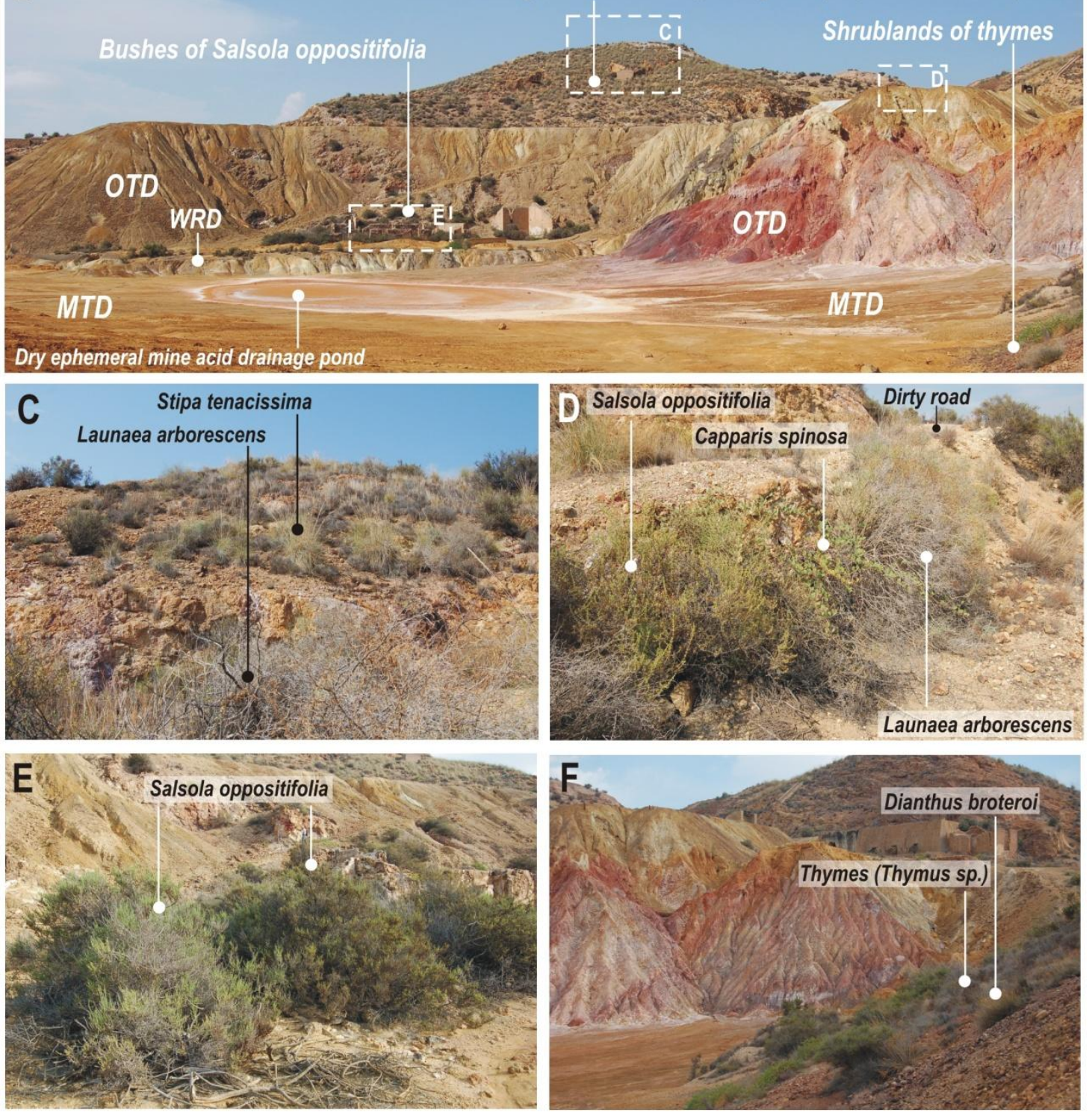

Figure 5 


\section{ACCEPTED MANUSCRIPT}

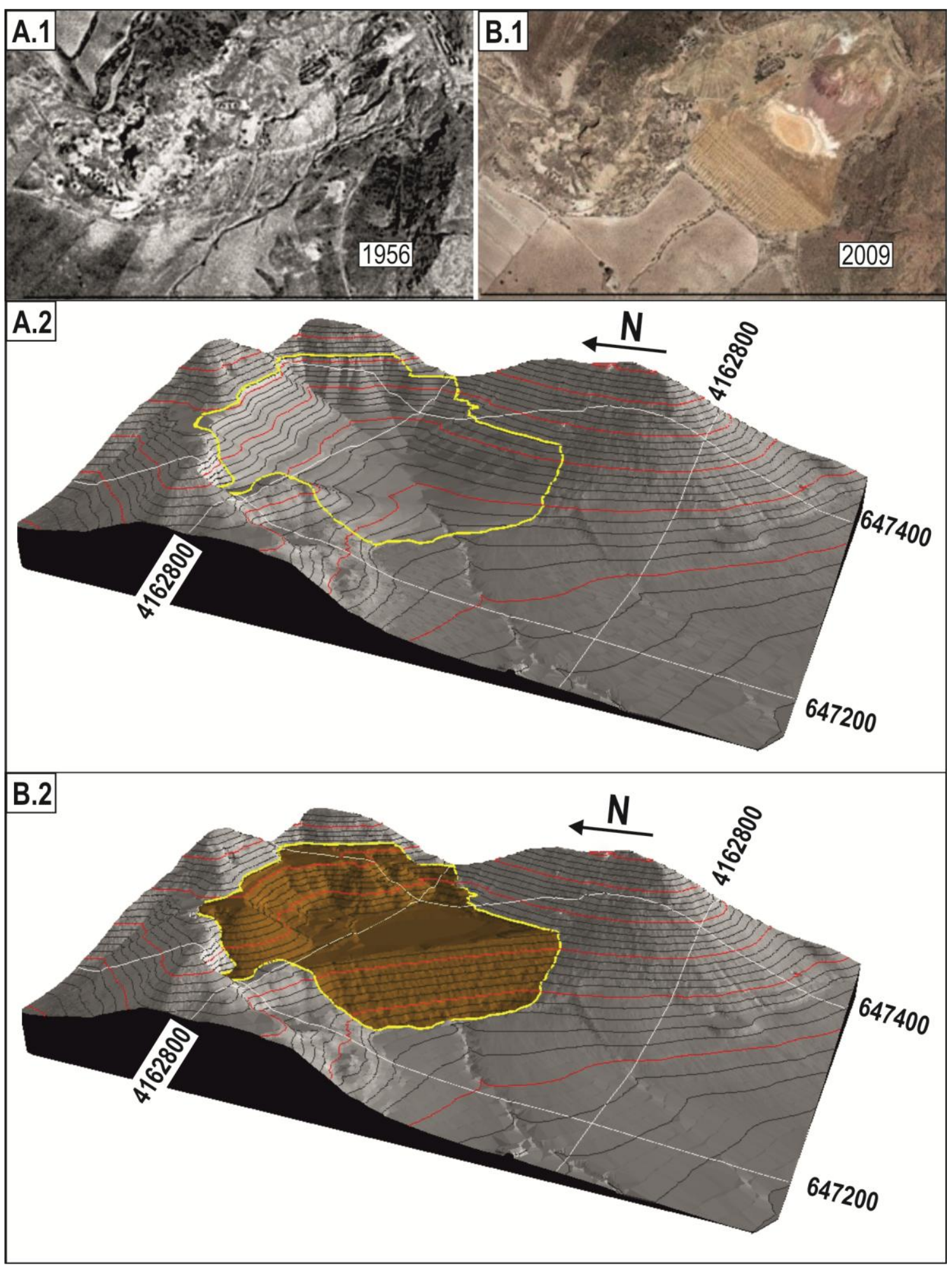

Figure 6 

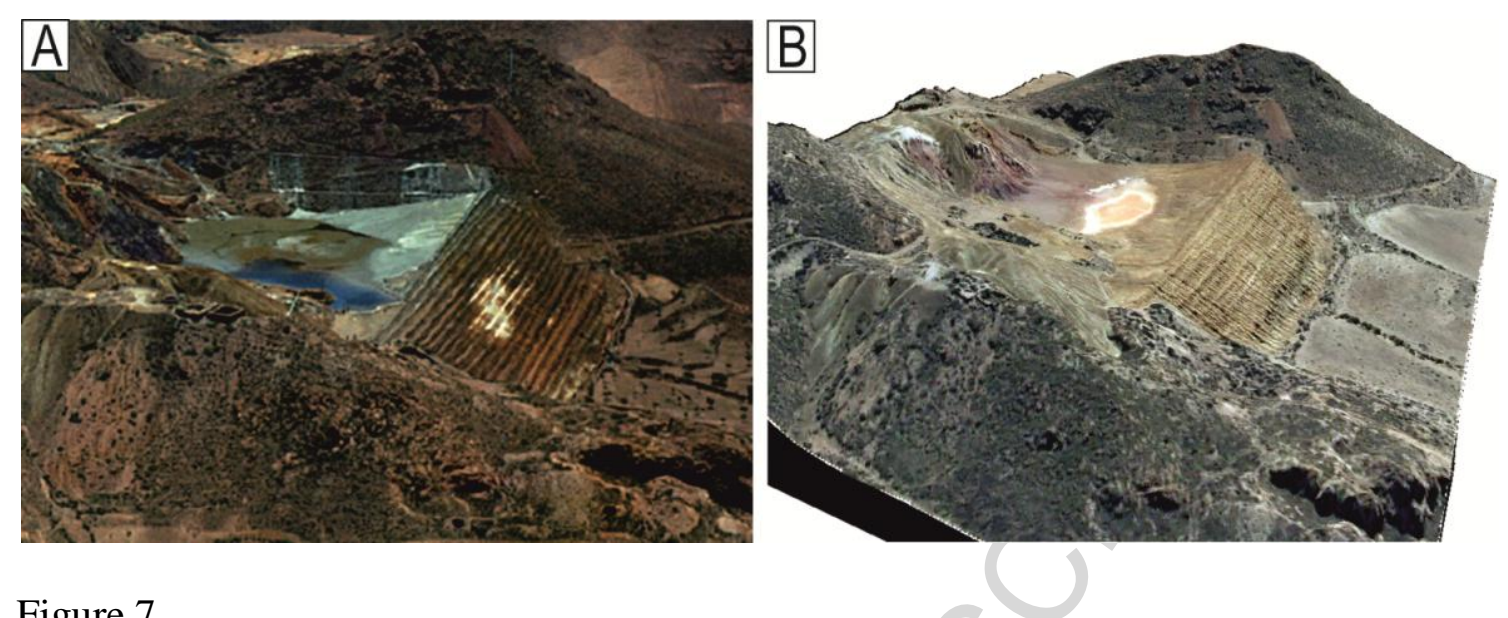

Figure 7 


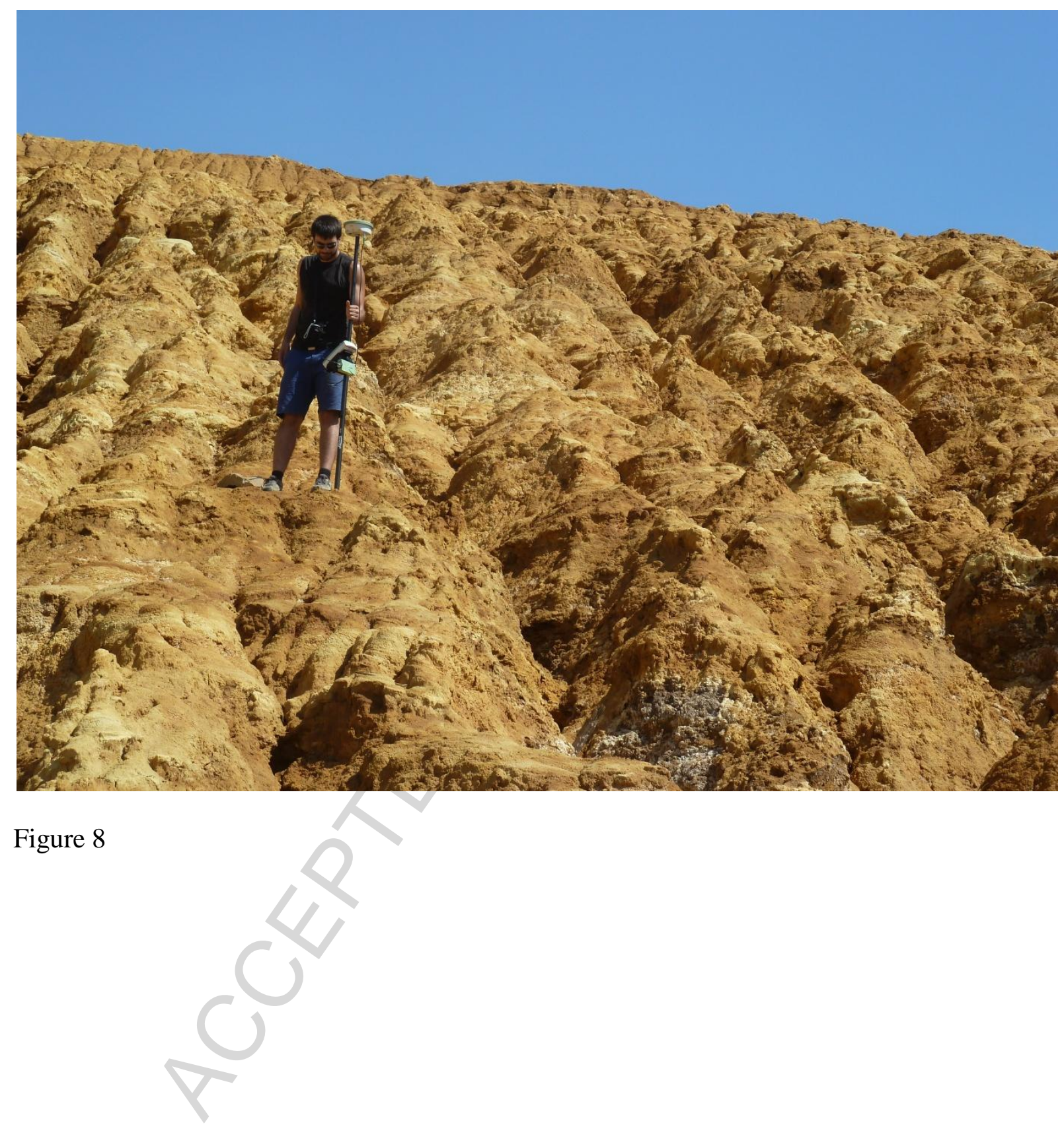



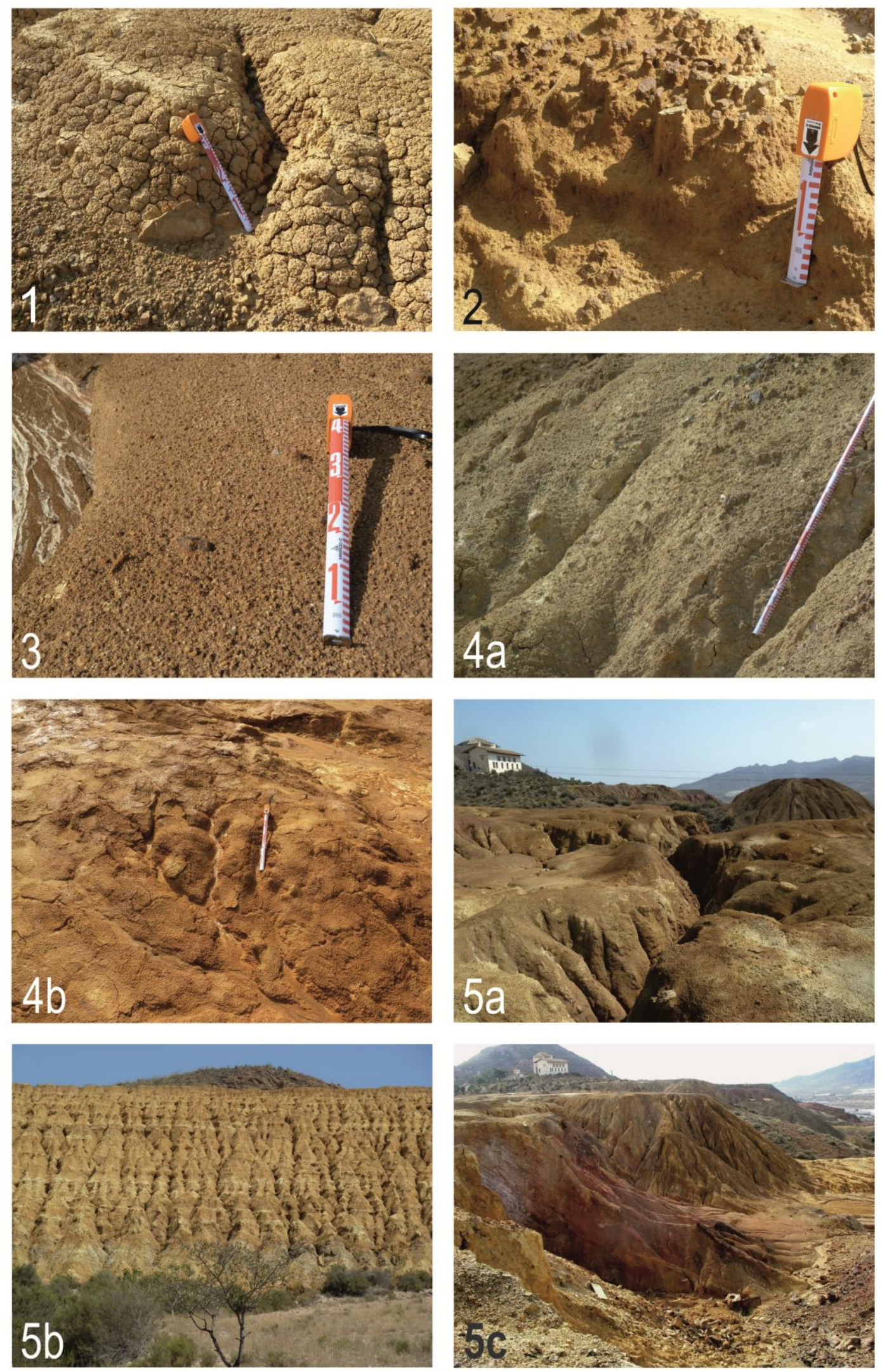

Figure 9 

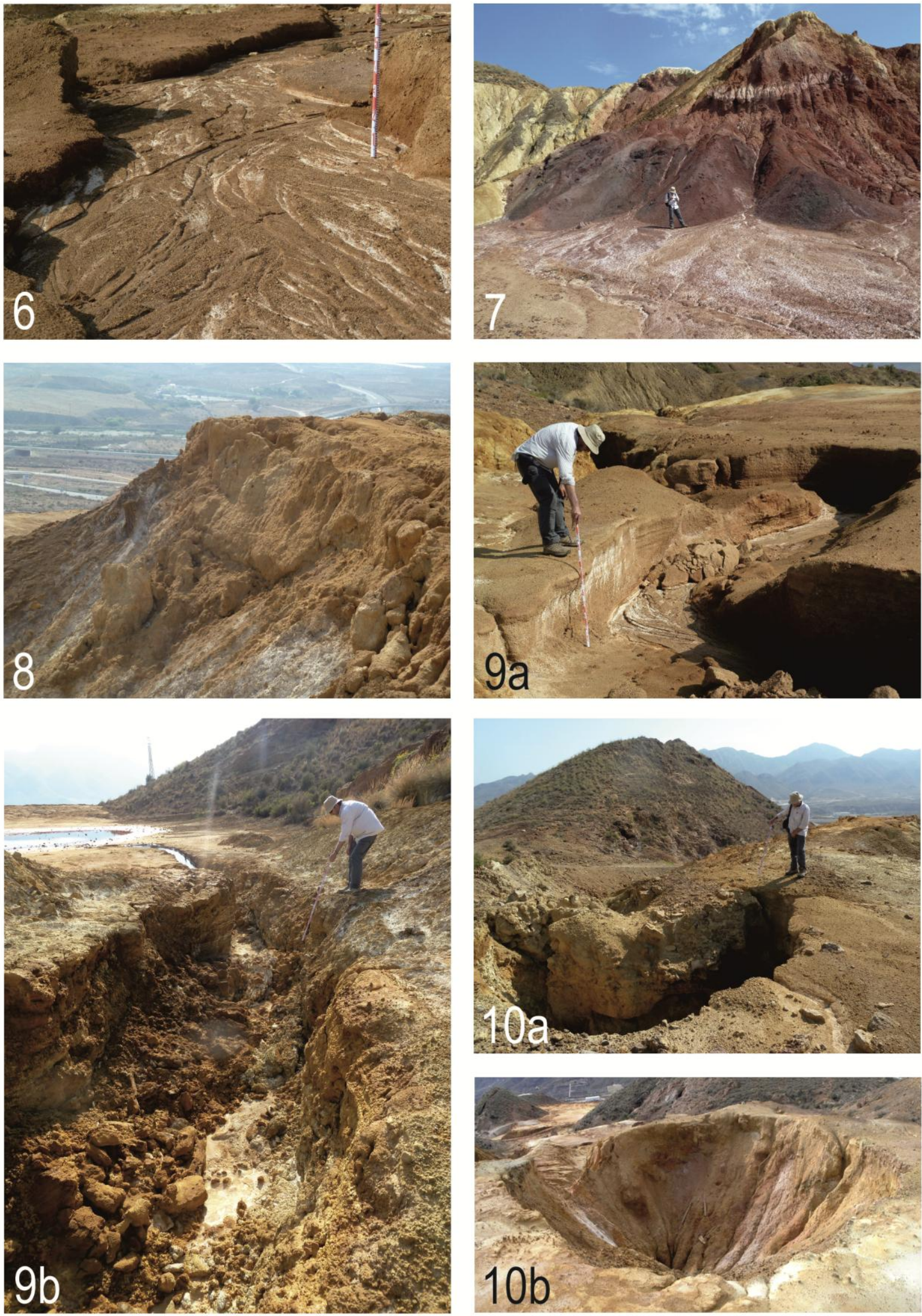

Figure $9 b$ 


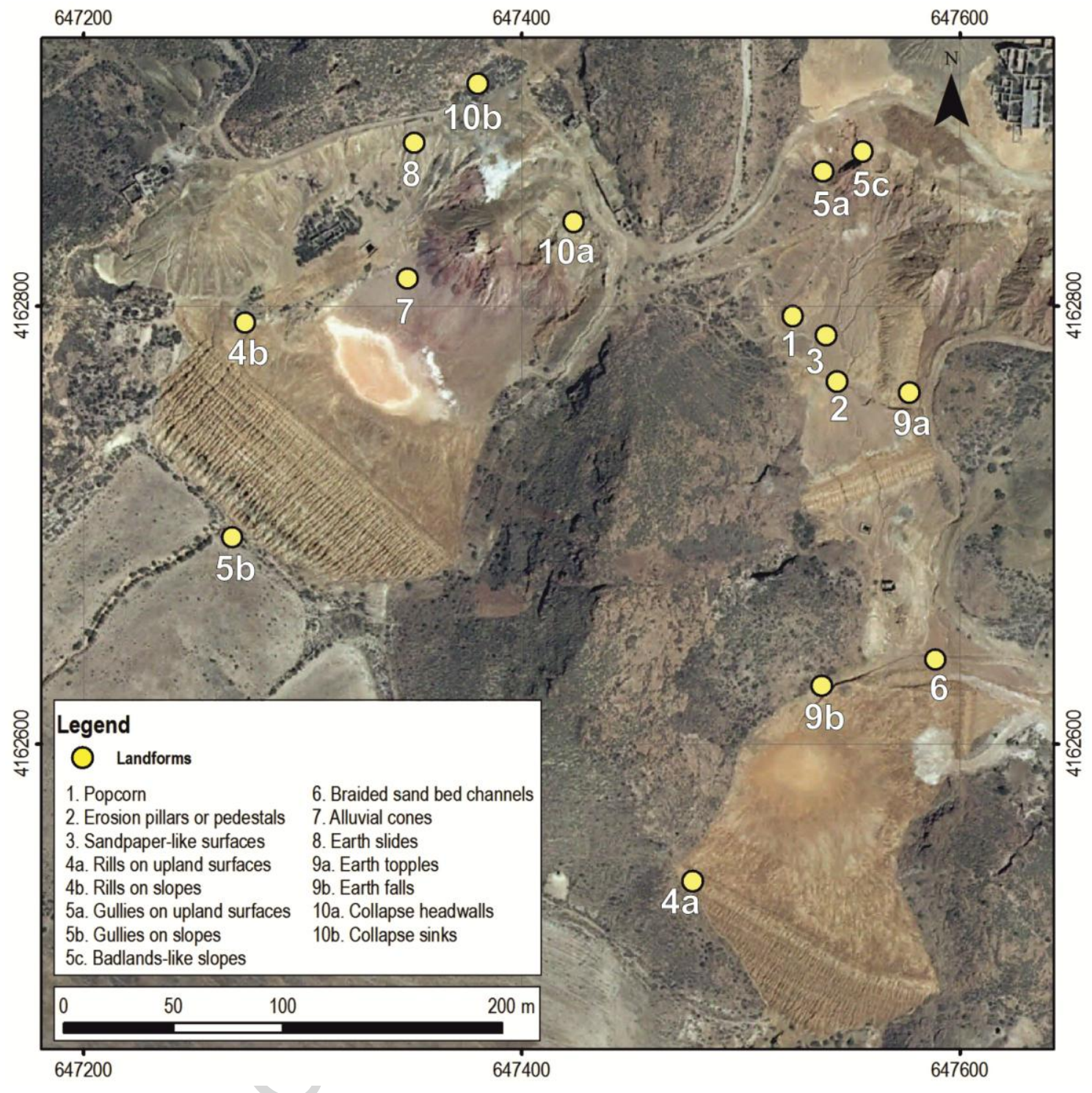

Figure 10 


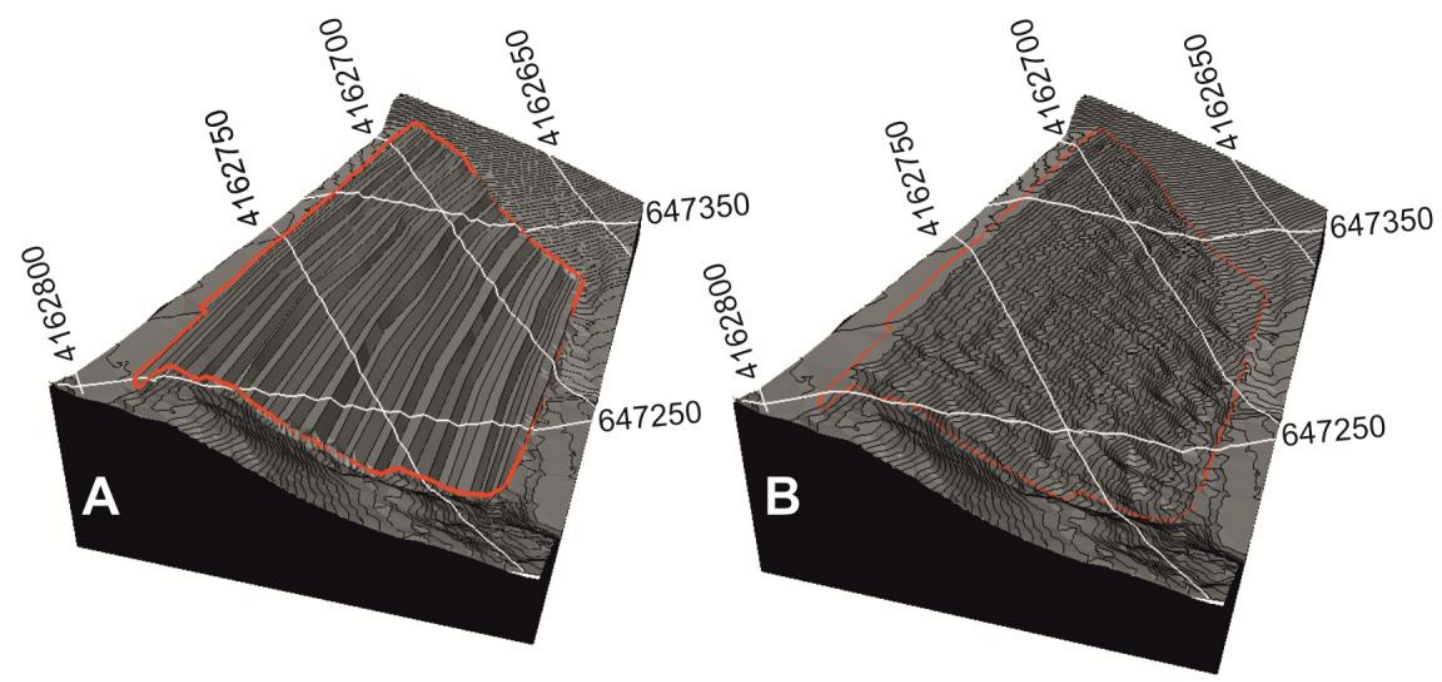

Figure 11 

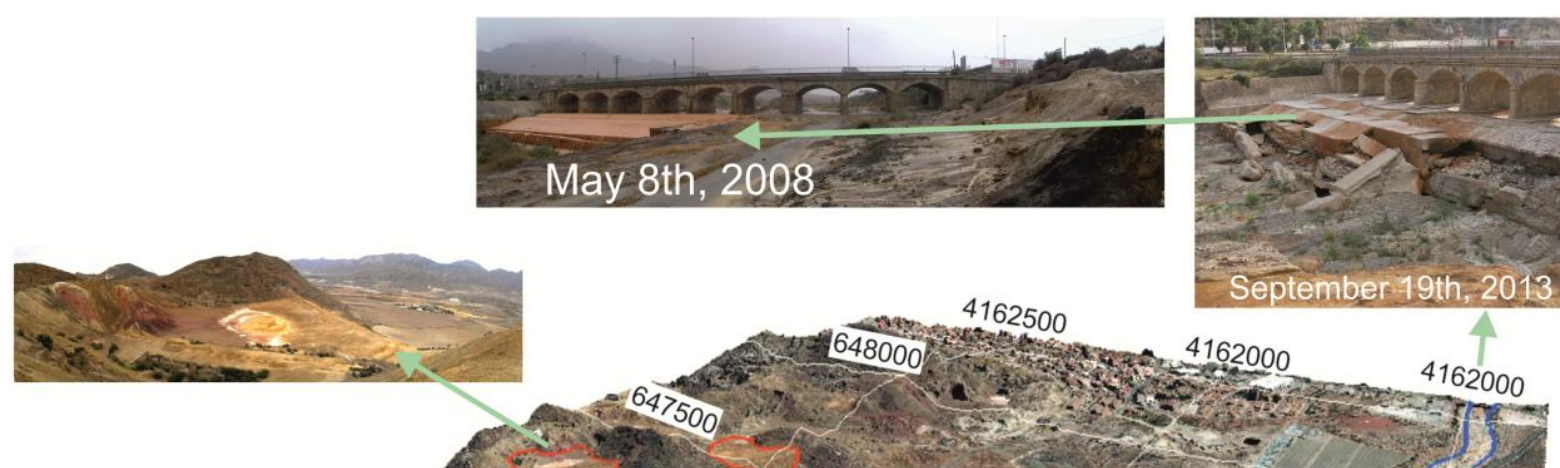

$64 \operatorname{sen}^{2}$
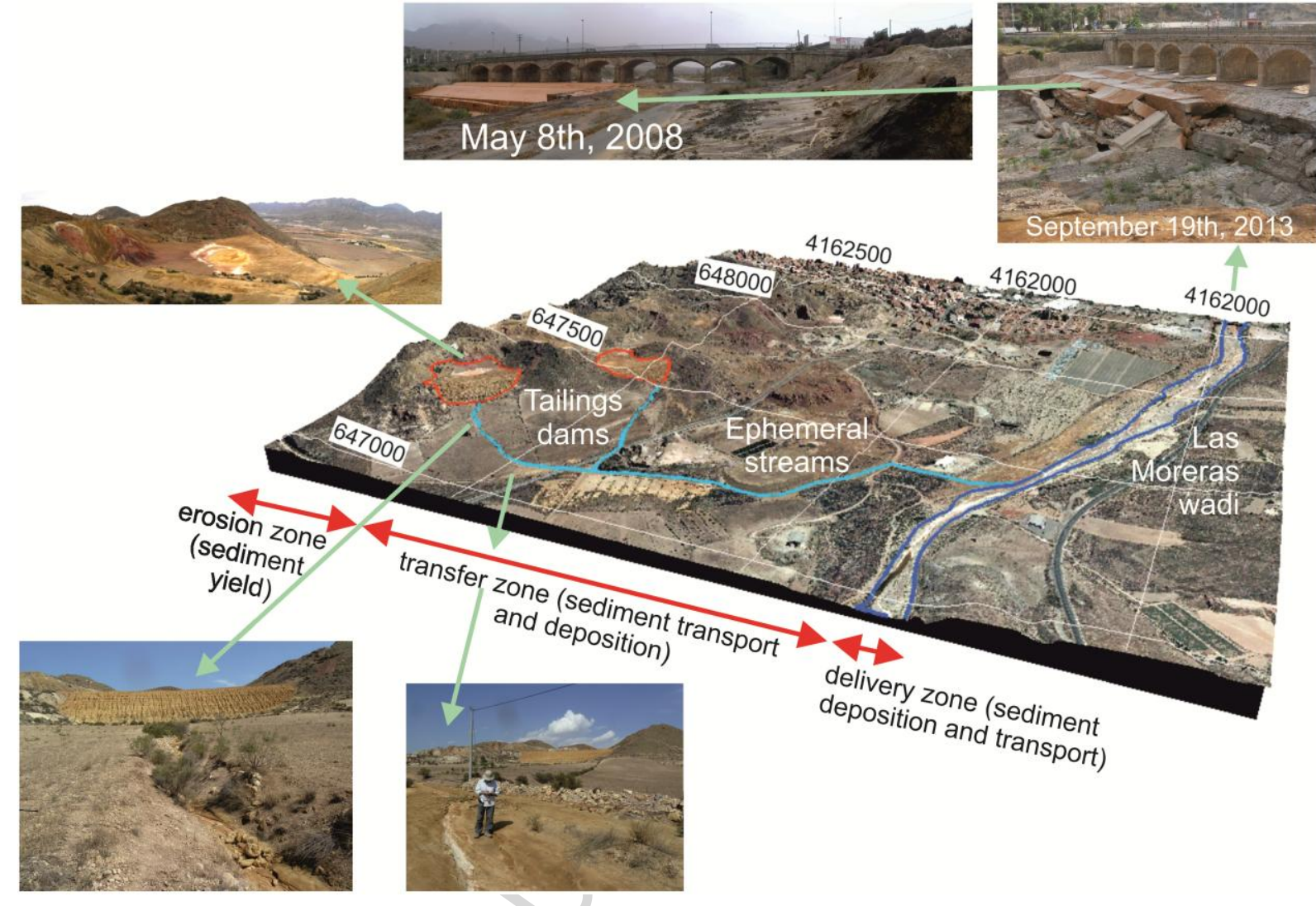

Tailings

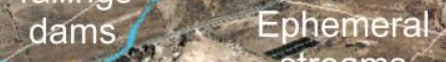

$14 a$ on streams

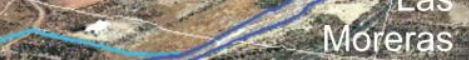

Figure 12
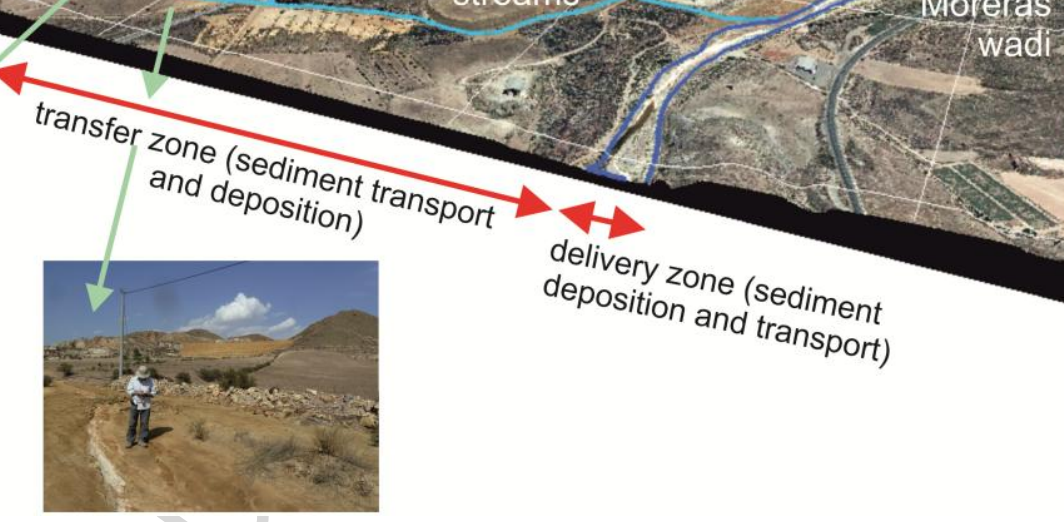

(sedimene yield)

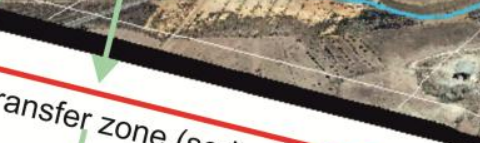

n)

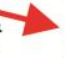

delivery

deposition and (sediment

nd transport) 


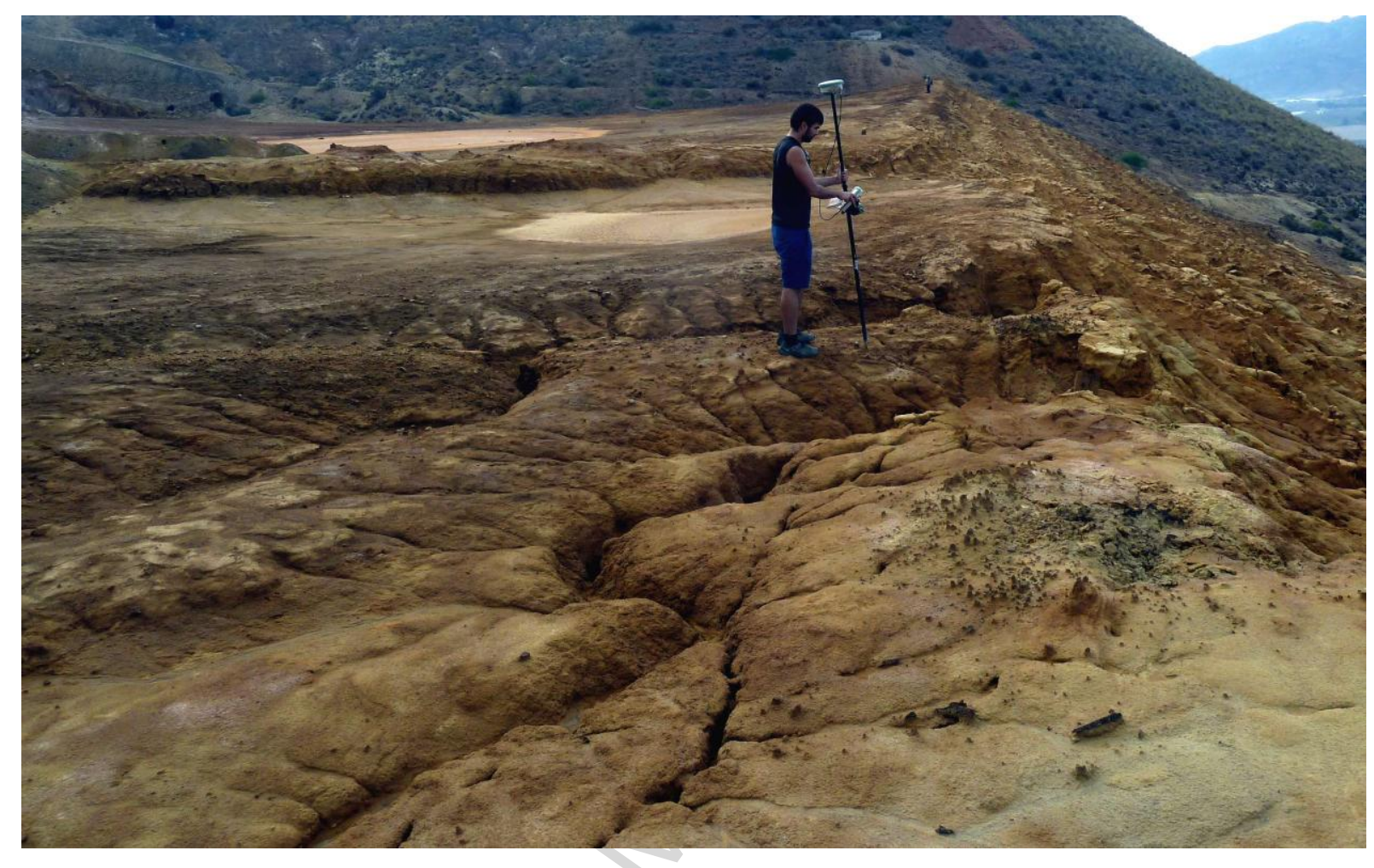

Figure 13

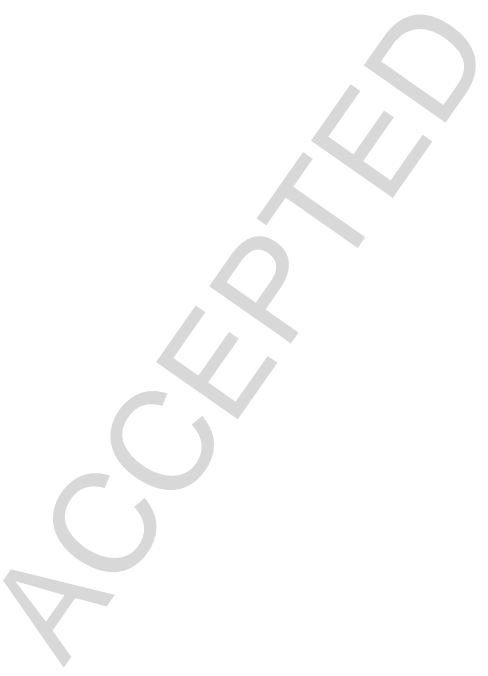




\section{Highlights}

This article:

- blends tailings' landform classifications with erosion quantifications using GIS;

- relates geomorphic changes in tailings deposits to mineralogical changes;

- provides a discussion about addressing environmental actions related with tailings;

- proposes the restoration of tailings deposits through landform design; 